\title{
Agricultura no delta do rio Amazonas: colonos produtores de alimentos em Macapá no período colonial
}

Rosa Elizabeth Acevedo Marin - Professora e pesquisadora do Núcleo de Altos Estudos Amazônicos da UFPA

\section{Resumo}

Nos séculos XVII e XVIII, ocorre a expansão mundial das espécies de arroz cultivável mais conhecidas na atualidade. Nesse período, Portugal ensaiou transformar o delta do rio Amazonas em um "celeiro agrícola", introduzindo o projeto de rizicultura no Estado do Grão Pará. A colonização de Macapá e Mazagão começou com base nessa produção. Este artigo trata das questões relativas à mão-de-obra exigida pelo projeto e às técnicas de manufatura e de comercialização do produto empregadas pela Companhia Geral do Comércio do Grão Pará e Maranhão.

\section{Abstract}

During the 17th and 18th centuries there was a world wide expansion of different types of rice cultivated, more than the present-day During this period, Portugal attempted to transform the Amazon river delta into a rice granery , introducing rice cultivation in the state of Greater Pará (Grão Pará). The colonization of Macapá and Mazagão began on the basis of this rice production. This article addresses the issues relating to the supply of laborers required for this project and the manufacturing technology and commercialization of products employed by the Companhia Geral do Comércio do Grão Pará e Maranhão (General Company for Commerce in Greater Pará).

\section{Palavras-Chave}

rizicultura, colonização, manufatura, comercialização, Macapá e Mazagão, século XVIII.

\section{Keywords}

rice cultivation, colonization, manufacturing, commercialization, Macapá e Mazagão, 18th century 


\section{O DELTA DO RIO AMAZONAS, CELEIRO AGRÍCOLA}

A humanidade assistiu ao desenvolvimento de diversas civilizações agrícolas nos deltas dos rios, onde, progressivamente, formam-se terrenos sedimentares com alto potencial de fertilidade.

No delta do rio Yantze, no Sudeste asiático, desde o quinto milênio a.C., formaram-se comunidades agrícolas sofisticadas com densidade de população excepcional e possuidoras de habilidades técnicas no cultivo e manejo do arroz. O produto era um componente importante da alimentação e tinha ainda aplicações agronômicas vantajosas, dada sua utilidade para diminuir e combater a salinidade e recuperar solos inundáveis. No império japonês, na Mongólia, em regiões da Índia e do Norte da China, a rizicultura nos deltas e em terras inundadas expandiu-se, conquistando ainda novas terras durante o domínio colonial inglês.

O sucesso das civilizações rizicultoras, localizadas em formações deltaicas, é incontestável. No delta dos grandes rios dos Trópicos, a presença do arroz parecia uma condição natural, e o "deltaestuário" do rio Amazonas não é exceção. Qual o sucesso histórico do cultivo e do manejo dessa gramínea na formação hidromorfológica do delta do rio Amazonas, que está situado na área do Trópico Úmido e apresenta condições climatológicas semelhantes às da área do Sudeste asiático?

Em primeiro lugar, é preciso localizar e caracterizar a formação deltaica da Bacia Amazônica. A Bacia Amazônica agrupa um grande número de ilhas de origem fluvial do tipo deltaico, formando o "arquipélago" ao norte da ilha de Marajó, ocupando quase todo o estuário do Amazonas. Dele fazem parte as ilhas de Bailique, Mexiana, Caviana, Janaucu e Jurupara, fronteiras ao oceano. Mais para dentro do estuário do Amazonas, encontra-se o "arquipélago interior", assim denominado por Le Cointe (1922). Embora seja visitado pelas marés, apresenta características tipicamente fluviais. Dele fazem parte a ilha Grande de Gurupá, dos Porcos, do Pará, do Vieira Grande, Queimada, Mututi, Ituquara e dezenas de outras. O trecho final do rio Amazonas, com uma extensão de mais de $300 \mathrm{~km}$, caracterizase por esse grande número de ilhas e apresenta uma larga embocadura de mais de $150 \mathrm{~km}$ de abertura. O rio Amazonas entra em comunicação com quase todos seus afluentes por um ou diversos furos, que recebem, ao menos durante a cheia do Amazonas, as águas desse rio, acima da verdadeira confluência. O estuário é formado por grande número de rios maiores ou menores, compreendendo o tre- 
cho mais ou menos extenso do estuário que abrange o Sul do Marajó, mais o "estuário do Pará", que reúne sob essa denominação toda a série de "baías", desde a baía de Marajó até a de Portel, senão até a de Caxiuanã (FIBGE, 1991, p. 111-113).

A faixa de terras que forma as várzeas do rio Amazonas mostravase propícia ao arroz vermelho, espécie que "nascia espontaneamente nas varjas. E nas terras pantanosas, e do que plantarão, e beneficiarão comerão aqueles que não compravão o branco, que vinha de Portugal" (FERREIRA, 1983, p. 132). A espécie classificada como de origem brasileira recebeu o nome de Oryza nutica, diferente do arroz branco conhecido na Europa, pequeno e limpo. Essa variedade "da terra ainda que fosse vermelho" devia ser cultivada de acordo com a recomendação do Marques de Pombal a João Pereira Caldas, "porque sempre servia para o sustento da gente pobre" (FERREIRA, 1983, p. 132). No decorrer do tempo, mudaram tanto a espécie de arroz como os consumidores.

A diversidade de espécies de arroz nativo foi assinalada por João Daniel (1976, t. 2, p. 133):

[...] há pelos lagos do Amazonas naturaes, e sem cultivo algum, que só eles, se se aproveitassem, podiam carregar grandes frotas, mas se perdem nos mesmos lagos em que se criam por não haver quem o aproveite.

Na segunda metade do século XVIII, Portugal ensaiou transformar o delta amazônico e a planície fluvial (várzeas) em um celeiro agrícola. O cultivo e o beneficiamento local do arroz foram idealizados para o delta, mas também se incentivou o plantio de algodão. O conjunto de meios disponíveis favoreceu uma espécie de transição do extrativismo para a agricultura.

As ilhas de agricultura do século XVIII marcaram espaços delimitados do delta, diferenciando-se do século anterior, quando se estabeleceu como objetivo o domínio territorial por meio da organização e da defesa militar, do levantamento de fortes e feitorias. Para que se atingisse esse objetivo, outros auxílios expressivos partiram dos conventos e do sistema missionário. O passo dado no século XVIII projetou-se na estrutura agrária e camponesa posterior, especialmente por organizar redes e relações de poder nos grupos familiares dedicados à agricultura.

Os campos ou terras agricultáveis para o arroz encontravam-se amplamente distribuídos ao longo de todo o vale do rio Amazonas. Lagos, campinas, alagadiços ou terra firme constituíam-se em solos favoráveis ao cultivo desse cereal. No entendimento do Padre João Daniel 
(1976), a Amazônia era uma paisagem geográfica sem grandes entraves para a expansão da agricultura em questão. Nas terras da ilha de Marajó, havia cacau, café, canaviais, roças de mandioca, tabaco e o arroz natural das várzeas, até então muito pouco utilizado pela falta de transporte. Pensava o religioso que o fato de o arroz apresentar esse crescimento espontâneo permitiria, com pequenos cuidados, que cada sementeira resultasse em duas ou três colheitas por ano.

Em nenhuma parte melhor, que no Amazonas, se podia suprir toda a casta de pão com o arroz, visto serem as suas terras tão próprias para ele, que por si mesmas, naturalmente, e sem algum cultivo o estão produzindo todos os anos, como em outras regiões produzem erva ou feno (DANIEL, 1976, t. 2, p. 131).

O plantio permanente não seria difícil, pois, após duas ou três sementeiras, com o cuidado de retirar o mato e de impedir o crescimento de arbustos, obter-se-iam rápidos resultados. As terras úmidas ou alagadas nos tempos das cheias facilitariam o crescimento do arroz, que seria possível graças à irrigação e à drenagem alternadas. Os terrenos do delta do Amazonas eram bem úmidos e ficavam alagados no período das cheias. Apenas em uma pequena parte desse território, ocorreu a experiência agrícola no século XVIII.

Depois de quase um século de presença dos portugueses, iniciouse o ensaio mais ambicioso de agricultura para aproveitamento do delta e da planície fluvial com o plantio do arroz. Ressalte-se, porém, um dado importante: as civilizações indígenas pré-colombianas dessa zona não foram consumidoras desse cereal. No mundo cultural dos grupos indígenas, o arroz havia ficado de fora de seus hábitos alimentares. Mesmo assim, exploraram os recursos do meio físico por meio de uma diversidade de práticas agroextrativas. Na várzea essas práticas permitiram-lhes atingir níveis elevados de população e criar uma organização social complexa. Durante a fase pré-colombiana, os índios Inhengaibas e Aruans, dois dos grupos mais numerosos, concentraramse na ilha de Marajó; ali recriaram uma cultura agroalfarera diversa e de riqueza notável, com a fabricação de cerâmicas. A agricultura consistia na preparação de terras para o cultivo de tubérculos, associada à colheita, caça e pesca. Essa combinação favoreceu o aumento da população, que se espalhou por toda a ilha (NEVES, 1991). Mas a destruição da civilização marajoara processou-se rapidamente, e sobreveio o primeiro momento de declínio da agricultura. Várias aldeias foram atacadas na ilha e suas redondezas. Em 1617, os índios das aldeias do Caju e Mortiguara (nome antigo da baía de Marajó), sublevados, foram atacados por 
Francisco Caldeira, enquanto os Tucujus, localizados na costa de Macapá, acusados de alianças com os holandeses, foram ferozmente combatidos. Após vinte anos de luta dos índios contra os colonizadores, a paisagem humana mudou por completo. As ilhas da foz do Amazonas e de Gurupá transformaram-se no palco de batalhas entre portugueses, holandeses, ingleses e irlandeses, o que contribuiu para arrasar os antigos habitantes do delta. A partir do fim do século XVII, a rarefação dos índios no arquipélago interrompeu a expansão anterior da agricultura praticada em parte importante dos seus solos (campos e campinas) férteis. A depopulação foi extremamente nítida, e a obra missionária não deixou outras marcas na ilha. Na extensão do vale amazônico, as missões montaram um sistema agrário combinado com a organização dos índios aldeados em espaços próprios. As aldeias missionárias mostraram-se rentáveis na extração, na agricultura, na pesca, na caça e na criação de gado.

A formação de círculos de agricultura começa na região do deltaestuário, via de entrada do vale. Desde a costa setentrional tem-se acesso ao rio Amazonas, navegável em toda sua extensão, ao longo do qual organizaram-se zonas agrícolas que também apresentavam condições favoráveis à organização dos circuitos de escoamento e de comercialização da produção. Nos rios Marajó e Arari, da ilha de Marajó, realizaram-se as primeiras doações de sesmarias entre alguns colonos que começaram o cultivo de cana-de-açúcar e de tabaco. A agricultura próspera, embora seus resultados fossem modestos, se comparados à empresa inaciana na ilha, pode ser encarada como um exemplo de uma bem-sucedida acumulação de riquezas.

Não houve ausência de idéias a propósito do povoamento e das vantagens que resultariam da destinação agrícola do delta, por reconhecimento da qualidade dos terrenos. O Padre João Daniel, profundo conhecedor da ilha de Marajó, permitiu-se sugerir soluções hidráulicas para evitar os problemas de inundação das terras e para facilitar a circulação pelos rios. Sugeria o estabelecimento de colonos, que poderiam fazer grandes "searas de trigo e arroz", junto com culturas em sistema de consórcio, do tipo tabaco x milho grande x feijão ou arroz. Acreditava que o Marajó poderia acolher casais que também praticassem a criação de gado utilizando o sistema de coivara (400 braças divididas, em que o gado teria um sistema de rotação) (DANIEL, 1976, t. 1, p. 68). A criação vigorou como uma atividade e suplantou as antigas terras de lavoura. Estabeleceramse fazendas, e campos e campinas foram destinados para a criação extensiva; já em 1756, o rebanho vacum alcançava quatro mil cabeças. Progressivamente se acentuava a mudança da paisagem geográfica, nesse 
segundo momento de declínio da agricultura, posterior à desativação dos antigos aldeamentos indígenas. Pouco parecia restar após a expulsão das ordens religiosas, enquanto a nova organização econômica das fazendas ficou abaixo da eficiência das antigas missões da ilha. Foi esse o percurso na ocupação de outras ilhas do arquipélago, quando na extensão da várzea e terra firme a agricultura manteve-se acanhada.

Nas várzeas, onde o povoamento indígena havia desmoronado, surgiram os sítios da ocupação do século XVIII, para instalar novas vilas, organizar os primeiros colonos e a agricultura. Uma segunda zona importante situou-se na parte mais setentrional do delta, compreendendo a região de Macapá e a área mais meridional, circundando Belém, espaço reconhecido pelas suas excelentes terras agricultáveis. Nas primeiras sesmarias distribuídas entre os colonos da comarca de Belém, começou o plantio da cana-de-açúcar, a instalação de engenhos e o cultivo de mantimentos.

Nos vales dos rios Tocantins e no baixo Amazonas, algumas unidades de produção do tipo plantation alcançaram o tamanho comum no Nordeste, se comparadas aos dados sobre os plantéis de escravos e a superfície das unidades. As fazendas de cacau do baixo Amazonas e do Tocantins mostraram uma organização social e econômica desse tipo. Mandioca, feijão e milho eram alimentos destinados ao consumo interno; algodão e tabaco foram menos importantes na estatística agrícola. O arroz, importante na pauta de exportação, foi, em períodos críticos de falta de farinha, o substituto obrigatório na dieta alimentícia de remeiros e acompanhantes durante as demoradas expedições de colheita ou de demarcação das fronteiras. Mas é difícil precisar os cultivos e suas áreas. Conjectura-se que, em 1780, havia um milhão e meio de pés de cacau cultivado - ou "manso" como era chamado -, que ocupava o primeiro lugar nas exportações. O arroz estava em segundo lugar na escala de área cultivada (e exportação), sendo seguido pelo algodão.

A idéia de formar um celeiro agrícola no delta e na planície fluvial amazônica, como escreveu o Padre João Daniel, estava contida nos discursos das autoridades e orientou as políticas da segunda metade do século XVIII. A descrição volta-se para essa fase de expansão da agricultura inserida no projeto de colonização em Macapá.

A fase de montagem da colonização agrícola revela uma trama de relações sociais entre colonos e administradores, que se prolongaram fora do espaço interno do núcleo. As famílias de colonos estiveram submetidas a um sistema coercitivo, regulado por forças repressivas superiores àquelas referidas como objetivos de defesa, comumente destacados na literatura. 
Macapá e Mazagão inseriram-se de forma especial nesse projeto. Entre 1752 e 1754, chegaram imigrantes dos Açores, que se distribuíram em São Miguel do Guamá, Ourém, Tentugal e Bragança e ainda numa vila fundada no rio Xingu, enquanto algumas famílias ficaram em Macapá. Os "colonos açorianos" fixaram-se em condições extremamente precárias, que dificilmente lhes permitiriam enriquecer. Macapá e Mazagão foram diferentes na concepção e na gestão. As diferenças devem-se à profunda militarização e ao papel de colonossoldados destinados a praças estratégicas. Esse status implicou o recebimento de um tratamento especial por parte dos governadores do Pará. A autoridade máxima do Estado e os comandantes das duas vilas trocaram volumosa correspondência a propósito de decisões sobre o grupo. Desde a chegada dos "navios dos casais" às vilas, passou-se a relatar situações de emergência, de precariedade da instalação e de conflitos. Ante o aumento da tensão entre os colonos ou antevendo qualquer explosão de ânimo, Francisco de Xavier Mendonça Furtado deu instruções para conter os "novos moradores em paz", mas também para persuadi-los a trabalhar no cultivo das terras, antes que se instalasse entre eles o "vício da preguiça" ou o desprezo pelo trabalho manual. Os moradores não obedientes seriam amolestados ou castigados; a penalização máxima seria o envio à cidade, onde lhes seria infligido severo castigo, conforme as leis de sua Majestade. O trabalho da terra era obrigatório. A aplicação poderia ser premiada com honras; caso contrário, haveria punição. Chegou-se a proibir aos povoadores qualquer comunicação com os franceses de Caiena (MENDONÇA, 1963, p. 115-117).

Evidentemente as experiências dos colonos dependiam do poder dos administradores e estavam sujeitas às conjunturas do sistema colônial. Colono foi, pois, uma categoria administrativa, política e juridicamente importante, definida pelo Estado e reafirmada legalmente pelas práticas dos administradores. A transferência de parte dos colonos para o Grão Pará foi patrocinada pela Companhia do Comércio, com definição de objetivos e regras. Os mecanismos de ajuda e os auxílios prestados para sua instalação, assim como os papéis atribuídos (econômico, social e militar) estavam definidos em códigos de controle da administração local.

Durante a iniciativa de formação da colônia, houve investimento na entrada de famílias, na fixação de capitais locais, na adaptação de técnicas, na organização de um mercado de trabalho escravo, no incentivo de produtos e nas isenções para sua exportação. A entrada dos produtores nos circuitos mercantis significou, em muitos casos, o 
endividamento e a estagnação dos empreendimentos. O modelo de relações sociais tecidas entre os colonos e as instituições coloniais e as vicissitudes que o marcaram são problemas centrais da agricultura camponesa.

\section{ECONOMIA RIZÍCOLA COLONIAL}

Nos séculos XVII e XVIII, deu-se a expansão mundial das espécies agricultáveis de arroz mais conhecidas na atualidade ${ }^{1}$.Conhecido e consumido em Portugal desde 1384, proveniente do Extremo Oriente e do Islã, o cereal recebeu impulso no reinado de Dom José que, tardiamente, reconhecia a importância para as terras de ultramar e para o próprio Reino dessa cultura, que poderia resolver o problema da falta de cereais nas cidades. O consumo na metrópole continuou a depender dos esforços e dos resultados do cultivo no Brasil, pois, apesar das iniciativas de plantações, como no Alentejo e em Setúbal, as dificuldades, especialmente da falta de mão-de-obra para a colheita, não favoreceram o aumento da produção. Historicamente, o cultivo dessa gramínea acompanha-se do aumento da densidade populacional e do estabelecimento de estruturas sociais e políticas que fazem dela uma agricultura intensiva e a tornam simultaneamente desejável e realizável, como se constatou entre os povos asiáticos (HAUDRICOURT, 1987, p. 273; GOURIOU, 1984, p. 8).

Portugal enfrentava, na segunda metade do século XVIII, um grande deficit cerealífero. Sabe-se, porém, que os problemas agrários portugueses despertaram pouco interesse, de tal forma que a legislação em seu apoio resultou inócua. Para os problemas da produção agrícola do Reino, não houve proposta de reforma ou de renovação dos sistemas de produção. Os princípios mercantilistas norteavam a política portuguesa. Com essa orientação, as reformas pombalinas encontraram uma saída temporária para a crise da economia metropolitana por meio da reorientação da política de exploração das colônias. As atenções concentraram-se no sistema de transporte com o intuito de assegurar uma maior eficiência na circulação dos produtos. O Alvará de 1773 resume a inspiração dessas medidas práticas, buscando assegurar as vantagens de transferências de bens dos lugares da produção para os locais de valorização:

1 A espécie Oryza glaberrima teria sido introduzida na Guiana e na América Central no período do tráfico de escravos, mas, em áreas da costa africana, sua região de origem,o cultivo diminui. 
consistindo a sustentação e as riquezas essenciais de todos os povos nos primitivos cabedais que produzem a lavoura e a indústria dos habitantes deles, devendo animar-se a primeira e favorecer-se a segunda de sorte que os frutos naturais e industriais que sobejam en uns lugares e constituem neles como capital inútil e morto possam renascer e fazer-se lucrosos pela exportação para outros (MACEDO, 1951, p. 203).

As capitanias do Maranhão, Grão Pará e Rio de Janeiro foram três grandes produtoras de arroz do período colonial. Em 1781, todo o arroz consumido em Portugal provinha do Brasil (MARQUES, 1983, p. 436). A rizicultura do fim do século XVIII teve importante crescimento graças aos incentivos da Coroa, ao tipo de isenção alfandegária em vigor entre 1761 e 1804. O decreto de 5 de janeiro de 1761 isentou por dez anos todo o arroz remetido dos portos do Brasil ao Reino (BRASIL, 1928, p. 309-310). Nesse mesmo ano, outro decreto isentou o gênero de qualquer emolumento. Ambos os decretos foram implementados em 1763 e complementados por medidas que asseguravam a introdução dos moinhos de beneficiamento do arroz. Alguns moradores foram beneficiados com a concessão para importar as peças do Reino e também com facilidades de crédito de longo prazo para a compra de escravos africanos. A expansão das exportações desse ramo de cultura alimentícia foi bastante estimulada. De certa forma, essas medidas generalizaram-se nas três capitanias e, no decorrer de sua implementação, fizeram do arroz um produto importante na história agrária do Brasil e do Pará.

A expansão desse cultivo no Rio de Janeiro desde 1781 produziu excedentes suficientes para o consumo interno e ainda quantidades crescentes, reexportadas de Lisboa para Londres, Hamburgo, Roterdam, Gênova, Marselha, etc. (BOXER, 1969, p. 192). A comercialização foi a razão do sucesso do produto no final do século XVIII. Entre 1783 e 1787, a curva das exportações de arroz do Brasil mostrava uma fase de prosperidade, apresentando um intervalo de estagnação entre 1792 e 1803. As duas primeiras décadas do século seguinte constituíram um período de aumento de preços, embora a queda mais acentuada tenha ocorrido durante as guerras napoleônicas. Para Jhonson, o interesse por alguns cultivos deveu-se ao aumento dos intercâmbios por força de trabalho, e assim a entrada de escravos da África favoreceu a expansão do mercado dos produtos brasileiros arroz, algodão, açúcar e café - na Europa (JHONSON apud ALDEN, 1973, p. 250-251). 
Nas terras secas do Maranhão, o arroz ${ }^{2}$ expandiu-se paralelamente às plantações de algodão, formando uma área de agricultura de exportação. Os plantios iniciaram em 1765-66 e tiveram uma primeira fase de baixo rendimento por causa da falta de chuvas. Nas freguesias de Nossa Senhora do Rosário, Nossa Senhora das Dores, Cuma e na zona de maior importância econômica - os vales do Itapecuru e Mearim até Cachoeira Grande -, ampliou-se o cultivo do arroz e do algodão. As plantações substituíam os engenhos de açúcar, do tempo dos holandeses, ao longo da denominada Ribeira do Itapecuru, a mais povoada. Nesse mesmo período, registrou-se a entrada de 10.710 escravos (6.025 homens e 4.685 mulheres), isto em fase de crise do mercado escravista (GAIOSO, 1970, p. 101-104; 163; 227).

Os lavradores de arroz de Macapá como os do Maranhão receberam as sementes do arroz Carolina, provenientes das zonas litorâneas de Carolina do Sul, onde se implantaram grandes fazendas escravistas produtoras de arroz. Embora esse tipo fosse mais aceito comercialmente, também cultivavam o arroz miúdo, contrariando com isso os mandatos e expondo-se a sanções pesadas. É importante examinar, no caso maranhense, a persistência do cultivo do arroz entre pequenos produtores ao longo do tempo, o que dá uma idéia da formação de uma "civilização do arroz", como marca dos agricultores migrantes. No Grão Pará, foi sobretudo em Macapá e nas áreas vizinhas que o projeto rizícola apareceu de forma mais acabada e intensa durante trinta anos. É essa descontinuidade que interessa à história. Entre os "colonos" ou "lavradores" que ocuparam as vilas de Bragança, Ourém, Irituia, Odivelas, Nova de El Rei, Cintra e Turiassu, proliferaram os pequenos

\footnotetext{
${ }^{2}$ Segundo Gaioso (1970), no Maranhão, a primeira plantação de arroz foi pouco produtiva pela falta de chuvas, e o autor insiste em circunstâncias naturais adversas (regime climático, tipo de solos e distância das áreas de cultivo). As primeiras regiões produtoras do Maranhão passaram, a partir de 1773, para a montagem de engenhos por particulares. Lourenço Belfort recebeu a primeira concessão para instalar um moinho. Um ano depois, ordenou-se a instalação de mais 50 moinhos e pilões, segundo o modelo de Belfort, e sua repartição gratuita. O preço caiu em 1774, de 400 para 350 réis, e conferia-se um estoque elevado em Lisboa. O empreendimento maranhense de cultivo do arroz tomou características de plantation, com indicadores de fortalecimento, na conjuntura de alimentos, do preço de algodão. Os produtores maranhenses recebiam os preços mais baixos pelo arroz, mas exportavam maiores quantidades. Nessa capitania, construíram-se mais moinhos que no Pará. O arroz no Maranhão tendeu a estabilizar uma população. Segundo o recenseamento de 1777, os plantadores na "ilha Cuma e Itapecuru aportaram a Fazenda Real 50\% de dízimos como regiões produtoras de algodão depois do arroz" (GAIOSO, 1970, p. 227). O arroz no Maranhão conquistou as terras secas, como no resto do Brasil, onde as áreas plantadas correspondem, na maior extensão, a esse sistema de cultivo (sobre a decadência da lavoura maranhense, ver ALMEIDA, 1983).
} 
domínios com plantios de café, tabaco, milho, feijão, algodão, mandioca e, em alguns casos, arroz. Entre essas vilas, destacava-se Turiassu, por exportar arroz e algodão para o Maranhão. As vilas de Beja, Baião e Cametá vendiam parte da produção de pequenos arrozais em Belém, onde se podiam ver os dois tipos, em pequenas quantidades. Entre esses lavradores, reconhecem-se as formas de organização e a malha de relações nas quais se articularam com grandes plantadores, comerciantes e o Estado. Não é menos certo que essas formas têm limites externos para realizar sua reprodução. Os registros da Companhia de Comércio sistematizados por Carreira (1988) apresentam lacunas na comercialização agrícola, talvez por falta de faturas e fichas de registro para vários anos - 1779, 1780 e 1781 - enquanto releva as exportações de arroz, especialmente no segundo intervalo - 1774-79 -, o que indica o impacto da comercialização (Gráfico 1).

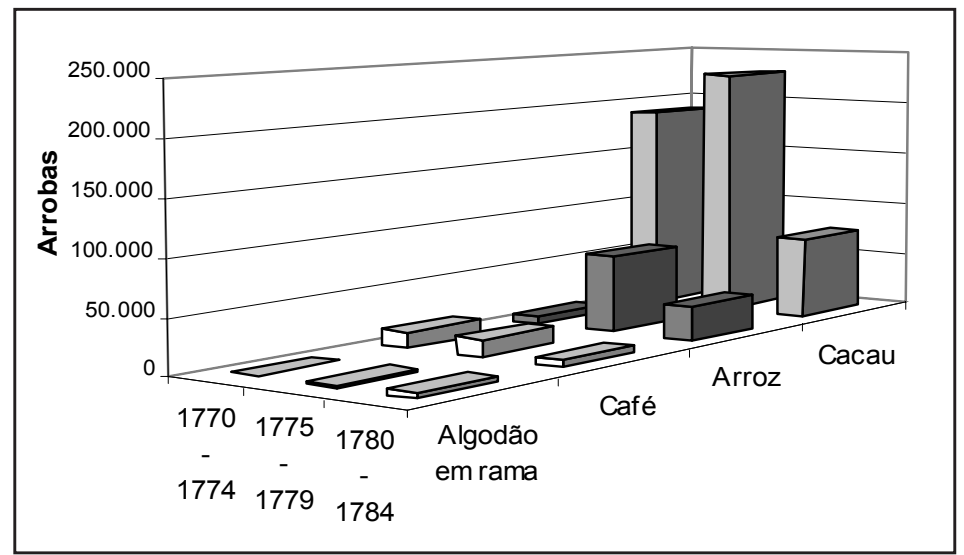

Gráfico 1: Produtos agrícolas exportados - Pará

Fonte: Carreira (1988, p. 234; 236).

Esses registros oferecem, apesar disso, interessantes informações. O arroz ocupou o segundo lugar nas exportações do Pará nos anos 177084. Os quatro produtos - cacau, arroz, café e algodão - experimentaram uma queda vertiginosa entre 1780 e 1784. O fato não pode ser atribuído mecanicamente à interrupção da comercialização, após o fim do monopólio da Companhia Geral de Comércio ${ }^{3}$.

\footnotetext{
${ }^{3}$ No levantamento de fontes arquivísticas existentes no Arquivo Público do Pará, constata-se a drástica redução dos documentos e códices sobre Macapá e Mazagão, fato que coincide com a queda de Pombal. Nova documentação poderá contribuir para acompanhar a crise final do sistema colonial e os desdobramentos na evolução da agricultura no delta e na planície fluvial amazônica.
} 


\section{COLONOS PLANTADORES DE ARROZ EM MACAPÁ}

Padre João Daniel havia feito referência às "excelentes paragens" na parte sul de São José de Macapá. Opinava que as ilhas formadas na boca do Amazonas eram talvez a "melhor porção de terras" de todo o rio, mas que era necessário povoá-las, "aumentarem as colônias". Os colonos deveriam dedicar-se à lavoura e à cultura das terras em plantações de algodão, arroz, mandioca, milho e feijão, que "não deviam ser acanhadas", além de cuidar da criação de gado bovino, aproveitando as campinas. Padre João Daniel recomendava ainda o cultivo do arroz "para os usos acostumados ou para lucrar e nisto adquiririão vantagens, sabendo descascar", pois dessa forma exportariam o produto para a Europa. Sugeria também que deveriam conhecer, experimentar e aproveitar as "cinco castas" conhecidas do cereal $^{4}$. O "arroz manso" era considerado o "arroz da Europa", mais graúdo, limpo, e logo passou a ser cultivado por alguns moradores; as "searas do arroz natural" distinguiam-se das do "arroz bravo"

Em parte da faixa de terras do denominado Cabo do Norte, distinguem-se as "paragens" mencionadas pelo religoso. Trata-se de uma zona que, por sua conformação hidrográfica, por seu relevo e por sua vegetação, é diferente de outros ambientes da bacia amazônica. É banhada por quatorze rios, todos delimitados dentro dos domínios portugueses, formada por ilhas de aluvião e pelo sistema de drenagem alimentado por rios, igarapés e vários lagos.

Em carta de 15 de outubro de 1685, Gomes Freire escrevia ao rei de Portugal sobre o Cabo do Norte:

[...] é um Padrão que está junto do Rio de Vicente Pinson perto de Cayana por onde se fez a demarcação do que pertencia aos Portuguezes, e aos Castelhanos, e o dito Padrão athé o Pará, tudo é chamado Cabo do Norte, comprehende toda a boca do Rio das Amazonas, que se entende ter perto de oitenta Legoas de largura, porém com muitas ilhas, e algumas grandes (REIS, 1993, v. 1, p. 74)

A geografia contemporânea incorpora esses fluxos de água à descrição dos elementos mais importantes da área - a drenagem continental e a sua subordinação à massa oceânica. A planície litorânea mostra conti-

\footnotetext{
${ }^{4}$ João Daniel aconselhava plantar o de maior rendimento, de menor tempo de frutificação e aquele que possuísse melhor gosto (DANIEL, 1976, t. 2, p. 132-133).

${ }^{5}$ Vandelli identificou o arroz próprio do Brasil como Oryza nutica e o arroz introduzido do Velho Mundo como sendo de origem asiática. VANDELLI, Domingos. Os Portugueses do século XVI e a História Natural do Brasil. Citado por: FERREIRA, Alexandre Rodrigues. Revista de História, Ano XV, n. 57-60, 1926, p. 51.
} 
nuidade com a planície continental, e ambas são atingidas pelo regime semidiumo das marés oceânicas, de forte amplitude. A grande bacia dos rios Araguari-Amapari é a de maior importância. Esses dois cursos de água seguem um trajeto sentido Norte-Sul, até se encontrarem com as águas do oceano Atlântico. As bacias pequenas dominam no Sul do rio Araguari e integram uma rede que se caracteriza por ser mais alongada do que larga. A região dos Lagos constitui uma rede intrincada de canais, de igarapés, situada entre os cursos do Amapá e Araguari. Região fisiográfica da planície, é formada por cordões litorâneos, por cursos fluviais e por uma área de transição ou piedmont, no compartimento que se delimita a partir do rio Araguari e que acompanha a margem do rio Amazonas. Esse espaço é constituído por dois elementos de mesma origem: a várzea alta e a várzea baixa, que recebem os sedimentos do rio Amazonas. A vegetação é variada e integrada ao relevo, à natureza do solo e ao regime de inundação. Predominam a "floresta de várzea dos altos cursos" e as "matas de várzea do baixo curso". Nos contornos das áreas inundáveis ou nas linhas de drenagem dos campos, localizam-se solos denominados "ilhas de mata" ou "bracinhos". São terrenos com melhores qualidades para a agricultura pela deposição dos sedimentos transportados pelos rios e mares, o que contrabalança o problema da lixiviação por efeito da alta pluviosidade (IBGE, 1956). Braun escreveu, em 1784, sobre suas "campanhas de planícies altas e escalvadas", com interposição de pequenas matas, correndo pelas faldas de toda a cordilheira que divide a Guiana (BRAUN, 1849).

As terras do Cabo do Norte receberam, com a entrada de colonos embarcados em Portugal, com os escravos introduzidos da África e com indígenas mobilizados de locais diversos do vale amazônico, um sopro de povoamento. Macapá, situada a 36 léguas do Cabo do Norte, foi o epicentro desse povoamento. Entre os colonos vindos para esses núcleos, fez-se a divisão das terras, algumas afetadas pelas marés litorâneas e que, por serem mais difíceis de cultivar, foram abandonadas. A vila de Macapá foi fundada em 1758, com povoadores "ilheos açorianos" e das ilhas Canárias, por ordem do rei D. João V. Constituiu-se um pequeno lugar encostado às muralhas da fortificação, com algumas centenas de colonos.

Em 1763, doze chefes de famílias do grupo transferido para Macapá receberam da Coroa, em uma distribuição bastante desigual, 156 vacas, 21 éguas e 8 touros. Na cidade delimitaram-se os pastoradores do gado. Realizava-se uma contagem permanente desse rebanho inicial: dez anos depois, a correspondência do Comandante de Macapá para o governador do Estado falava do aumento para 317 cabeças, e delas iria se 
dispor para os serviços reais. O gado era mobilizado para auxiliar nos trabalhos da fortificação. Os animais que morriam eram distribuídos entre os trabalhadores dos canteiros das obras e entre os doentes internados no hospital. Recomendava-se aos colonos buscar lucrar com o corte de madeiras, como a macacaúba encontrada nas vizinhanças.

Alguns administradores de Macapá e Mazagão incentivaram mais a agricultura, mesmo que esses núcleos funcionassem mais como reserva militar e salvaguarda de fronteira. A entrada de uma família de colonos dependia da decisão da administração, e cada uma devia colocar seus escravos à disposição para os trabalhos na fortificação, construção que durou mais de dez anos (1764-1773) e centralizou os recursos financeiros, a mão-de-obra dos indígenas e as atenções do governo. Definia-se um campo bastante amplo de compromissos e deveres dos colonos, estabelecidos unilateralmente. Os colonos deviam emprestar o serviço de seus escravos, o seu gado, além de atender os pedidos de horas de serviço ou as necessidades da coletividade com os gêneros colhidos. A construção da fortaleza merecia maiores atenções que a colônia agrícola. As rações de alimentos, rigidamente calculadas para dar conta dos residentes e de uma população colocada no canteiro de obras, eram disputadas por moradores e trabalhadores; o mesmo ocorria com os leitos no hospital.

Macapá, em contraposição ao domínio francês, devia transformarse numa possessão próspera. Apesar de seu caráter militar, o projeto necessitava apresentar uma faceta agrícola para concorrer com os planos de colonização da Guiana, empreendidos pela França, que havia perdido, após o tratado de Paris (1763), parte de suas colônias e apenas manteve as possessões de São Domingo, Guadalupe, Martinica, São Pedro e Miquelon e Guiana ${ }^{6}$. O balanço de fracasso do projeto francês na Guiana serviu ainda de alerta e de forte estímulo para o lado português.

Identifica-se uma primeira ambivalência do projeto: o de ser colônia agrícola e guarnição militar, ao mesmo tempo. Freqüentemente as autoridades deslocaram explicitamente (ou indicaram muito tangencialmente) o trabalho na agricultura em favor do segundo interesse. Alguns colonos, súditos e defensores dos interesses da Coroa fugiam das vilas, como os índios e os escravos.

Os moradores receberam instruções para dedicar-se ao trabalho agrícola. Por ordem expressa, definia-se que os soldados "lavrandei-

\footnotetext{
${ }^{6}$ Para essa possessão francesa o ministro Choiseul havia expedido um importante contingente de imigrantes (10.446) o mais elevado do Antigo Regime. Acompanhou essa decisão a retomada da organização do trafico de escravos negros de maneira a apoiar explorações agrícolas rentáveis (MAM-LAM-FOUCK, 1982. p.45).
} 
ros" (designação sinônimo de imigrantes) seriam "louvados e licenciados", obteriam "possessões de terreno com faculdade ainda para empregar os Indianos" das aldeias próximas, pagando-lhes "salários" como os jornaleiros de Portugal. Os colonos estavam em regime de disponibilidade compulsória, para servir como militares, o que implicou serem objeto de um sistema de requisição especial, como também experimentarem uma série de interferências na gestão da propriedade (escravos, animais e plantações). Isso, na verdade, privava as famílias de autonomia na gestão de seu cotidiano.

Os colonos de Macapá e Mazagão inseriram-se na malha da economia mercantil por meio da produção de arroz e algodão. A atividade principal - plantar arroz - não concorria com a mandioca generalizada nos "lugares de índios" e em vilas mais distantes. O sistema de cultivo era rentável, dado o baixo custo, o número de colheitas e o pouco tratamento exigido. Mas a visão desconexa dos sistemas de produção agrícola, beneficiamento e comercialização conseguiu provocar desequilíbrios, emperrar avanços técnicos apropriados à realidade local e elevar os rendimentos. A necessidade de atender as demandas externas - abastecimento da metrópole e escoamento de maquinário de origem européia - eliminou a possibilidade de desenvolvimento endógeno da cultura do arroz. Contudo, foi significativamente nesse campo das relações econômicas e de poder colonial que se definiu um certo padrão de economia agrícola. As formas sociais que se organizaram ajudam a entender a experiência dos colonos e dos sistemas agrários no delta do Amazonas.

Os moradores de Mazagão buscaram terras de cultivo nas ilhas Mutuaca e Pará, onde diminuía a salinização, além das terras às margens dos rios Preto, Maracá e no lago Juruti. Vila Vistosa Madre de Deus, situada a aproximadamente cinco léguas de Macapá ${ }^{7}$, foi fundada na margem setentrional do rio Anauarapucu, "sete léguas acima da sua bouca". Às margens desse rio, faziam-se plantios, em roças pequenas. Os colonos de Macapá utilizavam as ilhas próximas (Pará, Serraria, dos Porcos) para seus cultivos.

O empreendimento aproveitou-se do mercado de escravos importados, organizado pela Companhia de Comércio do Grão Pará e Maranhão. Mas, para calcular os proprietários de escravos em am-

\footnotetext{
${ }^{7}$ O trajeto entre Macapá e Vila Vistosa Madre de Deus exigia, segundo Braun, uma viagem de 17 horas, incluindo a espera provocada pelas "canoas ticarem em seco". O tempo de viagem era de uma hora e meia, da vila até o sítio do cirurgião-mor da vila, dono de engenho de arroz que fazia agricultura nas terras vizinhas. Esses detalhes ajudam a ilustrar o espaço da cultura e as referências de distância e de tempo na análise do transporte para os mercados de Macapá e Belém.
} 
bas as freguesias, precisava-se levar em conta que mais de uma centena pertencia à Câmara Municipal. Os primeiros colonos de vila Vistosa Madre de Deus receberam escravos de Benguela "para o adiantamento das lavouras que se reduziam ao arroz, algodão e urucu, além daquela porção de farinha necessária ao consumo da terra e ainda ao gasto da Fazenda Real" (VERGOLINO-HENRY, 1990, p. 176177). A vila de Macapá teria recebido 598 escravos (380 homens e 218 mulheres), um quarto deles adquirido pela administração municipal. A Companhia de Comércio introduziu a escravatura e abriu o crédito, entregando "aos pobres e industriosos moradores daquelles fertilissimos campos" um número pequeno de escravos (CARREIRA, 1988, p. 344). A colonização fez emergir o grupo de pequenos produtores escravistas, estabelecendo, na relação terra, trabalho e crédito, a dinâmica da agricultura mercantil. Mas a maior parte dos colonos foi definida como tendo "poucas possibilidades", segundo a classificação utilizada pelo recenseador de 1778. O projeto enfrentou problemas persistentes e teve resultados intermitentes, mostrados pelos administradores com veemência.

Nesse período do conjunto de povoações estabelecidas, São José de Macapá foi a vila mais estável, e o povoamento teve continuidade no tempo; em 1765, contava com 802 habitantes (554 maiores e 208 menores), população que, treze anos depois, havia mais que duplicado, com seus 1760 habitantes. Os chefes de família de São José de Macapá quase dobravam o número de Mazagão, e a produção de arroz quintuplicava. A construção de Mazagão foi iniciada em 1771, abrigando os habitantes da antiga praça portuguesa de Mazagão, fundada sobre o mar Atlântico e desocupada após o cercamento pelo rei de Marrocos $^{8}$. Nos três primeiros anos, foram transferidas 114 famílias, e a maioria dos seus membros declarou, no recenseamento de 1778, o ofício de lavrador.

A terceira vila foi Vistosa Madre de Deus. Recebeu "ilhéus funchalenses" e quarenta "degredados" de Lisboa, assentados no rio Anauarapucu por volta de 1769. O quarto sítio, situado à beira do rio Maracapucu, ficou conhecido como Santa Anna. As duas vilas saíram, em curtos períodos, de um estado letárgico. Vistosa Madre de Deus e Mazagão foram transferidas por causa da insalubridade dos sítios. Em

${ }^{8}$ Mazagão (Mazagam), situada no noroeste de Marrocos, perto do oceano Atlântico havia se destacado pelo comércio de lã e de grãos. Esteve ocupada pelos portugueses entre 1500 até 1772. A experiência no cultivo de grãos dos colonos não é mencionada nos documentos da colonização portuguesa. 
Macapá, existia uma fundamentada preocupação com os terrenos situados perto da fortaleza, onde reinava a insalubridade atribuída ao ritmo das marés e à proliferação de insetos, vetores de doenças. Os pântanos tornavam o clima insalubre. As "sessoens" (mal-estar físico generalizado) interrompiam os trabalhos de campo e faziam vítimas em número bastante elevado entre os trabalhadores indígenas, desnutridos e com baixa resistência às novas doenças. No grupo de migrantes transferido para Mazagão, houve mais mortes e deserções.

Durante o primeiro ano, as famílias mazagonistas receberam o pagamento de uma ajuda de instalação. Ao embarcar para as vilas, os colonos ocupavam os lugares atribuídos no núcleo e sujeitavam-se a uma série de normas ditadas pela administração. Já havia sido designada a casa para construir ou arrendar, as rações, o salário, os instrumentos, as terras, as sementes, as cabeças de gado e os trabalhadores ao seu serviço. Todos esses gastos eram contabilizados pela Companhia de Comércio do Grão Pará. A documentação revela que houve muita precariedade no núcleo. Não foram poucos os desistentes, e gerações de povoadores foram interrompidas.

Em quase meio século, mudou a paisagem humana, formou-se um novo mosaico; contudo, o povoamento ocorreu com muita instabilidade. Os movimentos de uma população flutuante marcaram o projeto. Nos canteiros de obras e nas roças, a flutuação maior foi de índios destribalizados que chegavam a representar 80\% dos trabalhadores. Alguns colonos foram favorecidos com a arregimentação contínua, por meio do Diretório, dessa força de trabalho para ajudar nas fases de semeadura, limpeza e colheita do arroz. Mulheres e rapazes indígenas distribuíram-se entre os cabeças de família que lavravam roças de arroz, algodão e milho e fabricavam panos de algodão vendidos em Belém. A agricultura familiar reunia alguns agregados e pessoas a soldada. Em 1778, em Mazagão, recensearam-se 310 cabeças de família (248 homens e 62 mulheres) e havia 396 escravos (254 homens e 141 mulheres). Macapá, com menos cabeças de famílias, tinha quase o dobro de escravos adultos em comparação com Mazagão (Tabela 1). 
Tabela 1: Famílias de Mazagão e Macapá - 1778.

\begin{tabular}{|c|c|c|c|c|c|c|c|c|}
\hline \multicolumn{5}{|c|}{ Mazagão } & \multicolumn{4}{|c|}{ Macapá } \\
\hline \multicolumn{3}{|c|}{ Homem } & \multicolumn{2}{|l|}{ Mulher } & \multicolumn{2}{|l|}{ Homem } & \multicolumn{2}{|l|}{ Mulher } \\
\hline & adulto & menor & adulto & menor & adulto & menor & adulto & menor \\
\hline $\begin{array}{l}\text { Cabeças de } \\
\text { família }\end{array}$ & 248 & & 62 & & 239 & & 35 & \\
\hline $\begin{array}{l}\text { Mulheres } \\
\text { filhos, } \\
\text { agrega- } \\
\text { dos, pa- } \\
\text { rentes }\end{array}$ & 116 & 223 & 339 & 164 & 97 & 236 & 20 & 188 \\
\hline $\begin{array}{l}\text { Pessoas da } \\
\text { soldada }\end{array}$ & 14 & & 30 & - & 28 & & 137 & 2 \\
\hline $\begin{array}{l}\text { Escravos } \\
\text { Total }\end{array}$ & $\begin{array}{l}208 \\
586\end{array}$ & $\begin{array}{c}46 \\
269\end{array}$ & $\begin{array}{l}102 \\
533\end{array}$ & $\begin{array}{c}39 \\
203\end{array}$ & $\begin{array}{l}345 \\
709\end{array}$ & $\begin{array}{c}38 \\
274\end{array}$ & $\begin{array}{l}134 \\
326\end{array}$ & $\begin{array}{c}64 \\
254\end{array}$ \\
\hline
\end{tabular}

Fonte: Mappa das Famílias que, a excepção das dos índios aldeados, se achavão existindo em cada huma da mayor parte das freguesias de ambas as capitanias do Estado do Para e de sua possibilidade e applicação no anno de 1778.

Menos da metade dos colonos estava na lista de clientes da Companhia para adquirir escravos a crédito e dos que receberam as primeiras sementes de arroz. O endividamento e o contrato de comercialização teciam uma malha complexa de hierarquia entre os colonos e foi fonte de tensão e de constantes conflitos. A entrega da produção de arroz era precedida de uma espécie de cerimônia, na qual o colono jurava ser verdadeira a sua declaração. A fiscalização depurada é percebida nas filigranas da documentação escrita pelos administradores de Macapá e Mazagão.

Sobre a colonização nas terras do Cabo Norte, existem as opiniões de autoridades do governo, viajantes, religiosos e historiadores. Concordam sobre o "fracasso" dos colonos e a insignificância a que ficaram reduzidas as vilas, mas reconhecem o êxito do arroz, da confecção de panos grosseiros de algodão. Tratase do reconhecimento dos resultados da comercialização. Aliás, Baena, ao escrever sobre a exportação de arroz do Pará, afirma que, no ano da abolição da Companhia de Comércio (1778), a colheita de Macapá foi de 40.000 alqueires, uma relação colonos/alqueire de arroz elevada (BAENA, 1969, p. 194). A propósito de Macapá, frisa-se o custo elevado para resultados ordinários. A insistência na decadência da agricultura dos colonos parte de comparações e expectativas criadas pelo regime de mercado que impôs excedentes cada vez maiores ao produtor. Mas a possibilidade de produzir excedente e 
vender defrontava-se com os problemas do mercado (preços) e do sistema de encargos imposto pelo Estado (dízimos), que reduziram a lucratividade do empreendimento familiar.

\section{TÉCNICAS DE BENEFICIAMENTO}

Se a cultura do arroz no Pará resultou de um acaso, como escreve Alexandre Rodrigues Ferreira, todos os atos posteriores foram calculados. O primeiro foi o envio, por João Baptista da Costa, de uma primeira amostra de arroz branco, proveniente da vila de Olivença, no rio Solimões, ao Sr. Manoel Bernardo de Mello Castro, de Macapá, em 1761, antes do ordenado no Alvará de 1763. O governador do Pará, João Pereira de Caldas, distribuiu as sementes de arroz entre os "lavradores mais hábeis", e assim se prosseguiu nos anos seguintes com o plantio da espécie nova, o que resultou no banimento do arroz vermelho ou arroz da terra.

Existem discordâncias a propósito do ano de introdução do arroz. Ferreira (1983, p. 132) indica o ano de 1762 para a produção e os carregamentos de remessas para Lisboa nos navios da Companhia de Comércio. Para Barata (1915), o envio da primeria remessa para Lisboa (30 sacos) ocorreu em 1773, posteriormente aos envios do Maranhão.

Os problemas e inovações relativos ao descasque do arroz constituem outro aspecto interessante na história agrária. Buscava-se uma variedade de cor branca, menos quebradiça na fase do descasque com auxílio de moinho, para aceitação no mercado europeu.

No projeto de cultura do arroz, priorizaram-se as técnicas de beneficiamento. O uso das tecnologias de descasque contribuiu para a apropriação de excedentes. As melhorias agronômicas introduzidas e as máquinas inventadas substituíram os antigos pilões, enquanto aparecia outra matéria bruta, os grãos inteiros, brancos, mais resistentes à quebra durante o descasque. Perseguia-se a durabilidade do maquinário. A combinação de novos grãos e máquinas ajudava a reduzir as desvantagens técnicas e podia mudar a posição no mercado. Quem dominava a técnica detinha um poder. Ela foi administrada e monopolizada por seus aperfeiçoadores, os mais próximos da Companhia de Comércio.

Depois de seis anos de cultivo do arroz, foi montada no Pará, perto de Belém, a primeira fábrica de descasque , em 1768. Localizava-se no igarapé São Joseph e resultou tecnicamente em um insucesso. O comprimento da máquina, movida por um único cavalo para 24 pilões, 
era desproporcional no eixo horizontal, que media 51 palmos. O braço da alavanca suspendia os pilões, provocando vibrações que desdentavam a máquina. O segundo aperfeiçoamento foi obra de Theodozio Constantino de Chermont, que utilizou a máquina na vila de Barcellos, capitania do Rio Negro. Chermont adotou o invento de Lourenço Belforte, mas com novos aperfeiçoamentos técnicos. Chermont, dono de máquina de arroz, foi o primeiro a embarcar 30 sacas de "arroz enviado como remessa". Logo foi imitado por várias pessoas, com autorização do administrador da Companhia, João Pereira Caldas.

A Companhia de Comércio introduziu, em 1773, "arneiros de fio de ferro, os mais commodos e próprios para joeirar o arroz", quando antes se usavam peles de animais. A primeira "atafona ou moinho do mos de pedra" foi adotado em substituição aos moinhos de madeira inventados por Belforte. Em 1774, em vários "subúrbios da cidade" e em sítios perto de Belém havia cinco máquinas diferentes construídas para o descasque. Em a "Memória sobre o Arroz", é citado Cipriano Vieira, que construiu um engenho de pilões para branquear o arroz e realizou ainda outras experiências para aperfeiçoar os engenhos de arroz. Cipriano Vieira importou doze pedras de moinho para o descasque e cortiças que facilitavam o branqueamento (FERREIRA, 1983, p. 132137). Eram usados dois cavalos para abaratar os custos. Imitações do modelo de ventilador de Cipriano Vieira foram introduzidas em Belém (FERREIRA, 1983, p. 132-137).

Parte das primeiras safras de arroz de Macapá foi transportada para o descasque em Belém. A primeira fábrica de beneficiamento da vila pertencia à Companhia de Comércio, porém, os agricultores não conseguiam descascar toda a produção. A máquina do modelo aperfeiçoado por Cipriano Vieira foi instalada em Macapá em $1775^{9}$. O engenho precisava da força de 28 pessoas e, na falta de braços, esteve inativo por vários anos. Tudo indica que não era um moinho pequeno, pela força humana e animal necessária para colocá-lo em atividade. As autoridades propuseram o emprego de cavalos, no lugar de bois, para mover o engenho (FERREIRA, 1983, p. 132-137).

Na correspondência de Macapá, insiste-se na falta de sementes para iniciar o trabalho nas roças, na primeira semana de agosto, época do plantio. Os administradores do projeto queixavam-se de atrasos na colheita ou do consumo dos grãos sem separar aqueles necessários ao

${ }^{9}$ A inovação de 1776 foi a substituição dos arneiros de fio de ferro por fios de latão, eliminando o desgaste pela ferrugem. A máquina de Cipriano Antunes Vieira foi vendida depois, em 1777, para o Maranhão. 
replantio. Registrava-se como muito desequilibrador o fato de faltarem canoas para transportar o arroz, que muitas vezes ficava danificado pela umidade excessiva e pela falta de proteção das chuvas.

0 melhoramento do cultivo não mereceu inovações técnicas, ainda que as áreas naturalmente inundadas precisassem de sistemas de drenagem, imprescindíveis nos arrozais de Macapá. Armazenamento e transporte ficaram igualmente de fora das inovações. Em 1781, quando a produção estava em alta, faltavam compradores. O governador do Pará fez três propostas aos agricultores macapaenses: colocar o antigo engenho de arroz da Companhia em funcionamento; "cobrarem-se melhor as dívidas da Companhia abonando nelas o arroz recebido dos devedores"; "aprontar-se mais cargas nos navios da mesma".

Priorizaram-se as técnicas de beneficiamento em detrimento do cultivo, armazenamento e transporte do arroz. Essa escolha protegia os interesses imediatos da Companhia de Comércio. O descasque despertou muita atenção, pois respondia por vantagens concedidas a terceiros. A empresa recebia e beneficiava o arroz dos colonos e remetia para a venda em Lisboa e, por intermédio de concessões de máquinas, favoreceu indivíduos que estiveram à frente do beneficiamento.

As trocas mantiveram à margem um grupo de camponeses. Os lavradores tinham que barganhar os preços do cereal com o "Administrador dos Arrozes". Desesperados com a situação, os camponeses fizeram petições em $1783^{10}$. Acumularam 150 requerimentos às autoridades. Solicitavam auxílios para as lavouras de arroz e algodão as que melhor pagavam os seus trabalhos - e indicavam as dificuldades provocadas pelo monopólio da compra e do transporte. As tensões da comercialização refletiam nas esferas institucionais, onde também os agricultores expressavam seus protestos.

O recenseamento de 1778 indica os rendimentos dos lavradores, ou quantidades monetárias ou o montante do que se "apurou da lavoura", Essa espécie de contabilidade foi detalhista, particularmente nos aspectos relacionados às unidades formadas por grupo familiares pequenos, com poucos agregados e sem escravos. Em Macapá, havia 447 escravos e, em Mazagão, 395. Na detalhada correspondência entre os administradores locais e o governador do Pará, revela-se a instabilidade e a distribuição da mão-de-obra para auxiliar a fase de colheita. O número de "jornaleiros" era insignificante. Oitenta e nove lavradores de Macapá compraram 343 escra-

\footnotetext{
${ }^{10}$ Muito significativa foi a recusa dos agricultores maranhenses à queda do preço do arroz de 1772/73, o que obrigou a Companhia a reavaliar e a aumentar o preço do arroz com casca para 400 réis e do descascado para 500 réis.
} 
vos, logo, a distribuição era bastante desigual. Trinta e nove não tinham escravo algum. Um grupo de 28 colonos possuía cada um o seu escravo. Dois grandes proprietários são identificados pelo ofício de "negociante e lavrador": um possuía 83 escravos e uma máquina de descascar arroz; o outro declarou 31 escravos. De fato, ambos eram mais negociantes do que "lavradores", haja vista a pequena quantidade de arroz produzida por suas lavoura (algo mais de 100 alqueires). Esses proprietários usufruíam de patente militar e, entre seus negócios, estava a compra de arroz. A polarização da riqueza e da pobreza assumia clara configuração.

Os agricultores não escravistas estavam sujeitos aos donos de máquinas de beneficiamento e aos compradores da produção. Circulavam na área de negócios fechada em torno de duas máquinas de arroz e de um grupo de compradores do produto. Naquele ano, os agricultores de Macapá declararam menos de mil alqueires de feijão e milho e uma quantidade irrisória de tabaco e café, o que reflete, portanto, uma certa diversificação da agricultura. Ainda trabalharam na extração, contabilizando 10.380 canadas de azeite de andiroba. O cultivo da canade-açúcar resultou na fabricação de 4980 canadas de aguardente.

Vários chefes de família tinham outro rendimento pelo trabalho dos seus teares, com fabricação de panos grossos de algodão feitos por escravas tecelãs e rendeiras. Na freguesia, contavam-se 738 cabeças de gado vacum e seis, de gado cavalar de nova produção ${ }^{11}$. Depreendese que, por períodos de curta duração, as condições de mercado foram favoráveis à recomposição da família camponesa em Macapá e Mazagão, com base na policultura e no extrativismo. Essa orientação reforçou-se após a libertação das rédeas da Companhia de Comércio e das amarras dos mercadores do arroz.

\section{EXPANSÃO DA RIZICULTURA}

0 cultivo do arroz em Macapá atendeu a duas demandas. A primeira, menor em resposta, correspondia às necessidades de abastecimento local num momento de afluxo de trabalhadores para a construção da fortaleza de São José e das vilas de colonização. O cereal entrava como parte da ração alimentícia ou era utilizado para o pagamento das tropas. No caso de escassez, ou de diminuição das rações de farinha de

\footnotetext{
${ }^{11}$ Mappa de todas famílias que existem na Freguezia de Sam Jozé de Macapá, da força das suas Lavouras e Serviços; e da quantidade e qualidade de efeitos e colheitas que ellas produzirão em todo o ano de 1778
} 
mandioca, distribuía-se arroz entre trabalhadores e soldados, o que contribuiu para a variação das quantidades exportadas. O arroz era o prato cotidiano na cidade de Macapá. A segunda demanda, mais importante, provinha da exportação do gênero para Lisboa. Daí derivaram diversas interferências, desde a mais grave e corrente - o transporte - até a série de despesas e custos de comercialização.

O transporte podia implicar perdas não somente pelo atraso, mas também por danificação do produto durante a viagem. A viagem de canoa de Macapá a Belém durava oito dias, e o estrago era provocado pelo contato do arroz com as paredes da canoa. Os moradores de Mazagão dependiam, muitas vezes, para o transporte da sua produção, da capacidade excedente das canoas de Macapá.

Entretanto, os problemas mais importantes estavam ligados à comercialização. O mercado e o preço, parte intrínseca da economia mercantil, pesaram no desempenho da economia agrícola e na evolução dessas formas camponesas. Essa economia agrícola estava alicerçada em cálculos e projetos de expansão, o que significava aumentar a produção de excedente pelos agricultores, nem sempre estimulados pelo preço de mercado.

As lavouras de arroz de Macapá, entre setembro de 1776 e abril de 1777, tiveram um rendimento de 20.654 alqueires $^{12}$. Por intermédio da Companhia de Comércio, foram remetidos a Lisboa 16.250 alqueires (80\%) e três particulares comercializaram a outra parte diretamente (APP Códice 174). Nos anos seguintes, as correspondências indicam uma queda da produção. É preciso, porém, observar a irregularidade das informações que permitiram levantar parcialmente as quantidades exportadas entre 1778 e 1781 (Tabele 2).

Tabela 2: Produção agrícola exportada por Macapá.

Gênero

\begin{tabular}{lccc}
\hline & 1778 & 1780 & 1781 \\
\hline Arroz (alqueire) $^{13}$ & 11.848 & 6.423 & 21.479 \\
\hline Algodão (arroba) & 2.504 & 1.078 & 1.979 \\
\hline Farinha (alqueire) & 380 & 1.875 & S.inf.
\end{tabular}

Fonte: APP Códices 201 (I 780), 210 (1781) e Mappa das Famílias, que, a excepção das dos índios aldeados se achavao existindo em cada huma da mayor parte das freguesias de ambas as capitanias do Estado do Pará e de sua possibilidade e applicação no anno de 1778.

\footnotetext{
${ }^{12}$ No documento, compara-se a produção do Maranhão e de Macapá: esta última representava um quarto da produção de Maranhão, praça com que competia (APP Códice 174, em anexo).

${ }^{13}$ Seria interessante observar que as medidas no período são muito variáveis. A referência às medidas de capacidade pode basear-se nos cálculos encontrados na edição da obra de Spix e Martius (1976, p. 273): "Para secos: Alqueire (4 quartas) 31, 171 ou 13,81 (port)".
} 
A queda da produção em 1780 mostra-se importante. Primeiro, os documentos indicam o aumento da superfície cultivada. No mês de abril de 1777, o comandante de Macapá, Manoel da Gama Lobo de Almada, remeteu ao governador do Pará o ambicioso "Plano pelo qual se offerece a que do porto de Macapá saião todos os annos ao menos cem mil de arrobas de arros" (ver Anexo). Esse projeto, escrito às vésperas do encerramento das atividades da Companhia de Comércio, insistia no aumento das exportações, supondo ainda que o fim da empresa comercial desestabilizaria parcialmente as redes de comercialização e a organização do transporte.

No plano listavam-se 162 lavradores e declarava-se contar efetivamente com 293 para a lavoura: homens de trabalho $110+172$ negros de Machado + 11 índios de Portaria. O plano previa a necessidade de mais 2007 trabalhadores, indicando o número de índios que deviam ser expedidos pelos diretores das vilas próximas. Outro detalhe é a relação homem vs produção, 617 alqueires vs homem. O crescimento da lavoura dependia de mais trabalhadores, inclusive índios, pois a Companhia Geral não mais importava escravos, nem os colonos podiam comprá-los. Ademais, era preciso adquirir machados e foices (1500 de cada) e receber 9132 alqueires de farinha para o sustento dos trabalhadores.

O plano ficou no papel, o fato concreto foi a dificuldade de encontrar compradores. Em 1781, em fase de alta da produção, faltavam compradores. Outros detalhes registrados na documentação foram o aumento de vendas diretas pelos agricultores e a formação de um grupo que tinha como atividade principal a compra no varejo da produção de arroz. Antonio Jose Vaz, proprietário de 83 escravos, havia colhido apenas 104 alqueires de arroz e 110 de algodão, mas aparece no Recenseamento de 1788 como tendo apurado $1.1488 \$ 200$ réis, o rendimento máximo em Macapá.

Depreende-se dos documentos que a situação econômica dos colonos era bastante diferenciada. Trinta por cento eram proprietários de escravos. Conferidos os nomes dos colonos (162) listados no Plano do comandante da vila com o recenseamento (274), identificamos 66 lavradores como "pessoas capazes de se lhes confiar a lavoura por experiência" (APP Códice 177, doc. 46) ou candidatos a plantar e colher 100.000 alqueires de arroz, como idealizou Lobo de Almada. Entre esses, quarenta e cinco colonos tinham no total 185 escravos, e um único colono, acima nomeado, 83 escravos. O importante é conferir a relação entre escravo e produção de arroz. O resultado é muito heterogêneo. O único cafuzo incluído, Dino da Silva, sem escravos, conseguiu produzir 115 alqueires de arroz, contando com seis membros na família. Antonio 
Jose Vaz declarou ter produzido a mesma quantidade. No grupo com até dois escravos, foi anotado o valor apurado na lavoura em réis, e poucas vezes se identificam as quantidades do produto. Mas repete-se freqüentemente uma produção de 100 alqueires de arroz para a maioria dos agricultores que contavam às vezes com a força de trabalho familiar, como é o caso de Paulo Ferreira, com 5 adultos e 6 menores. Os proprietários de mais de 5 escravos declararam ter produzido, em alguns casos, quantidades iguais às dos donos de 9 ou 10 escravos. Ainda se pode estabelecer outra relação, examinando os maiores produtores de arroz e seu plantel. Os produtores de mais de 1000 alqueires de arroz foram Juliao Alves da Costa, dono de 14 escravos (1100 alqueires), Andre Correa Picanço, senhor de 9 escravos (1400 alqueires), e D. Josefa Maria, dona de 6 escravos, que vendeu 1000 alqueires - originalmente, essa viúva destaca-se entre os cabeças de família mulheres (35 do sexo feminino) (ver Mapa). Nenhum deles contava com mais de 4 adultos na família para empregar na agricultura. Para os dois homens, destacamse os cargos de cirurgião-mor e de alferes auxiliar respectivamente. Provavelmente os três eram compradores de arroz.

Os agricultores de Mazagão venderam no ano do recenseamento 3430 alqueires de arroz e 470 de algodão, servindo-se de 94 escravos, e foram classificados como de "poucas possibilidades". No entanto, observa-se a anotação de rendimentos íntimos no total em que as lavouras pareciam menos prósperas.

0 recenseador de Macapá e Mazagão, extremamente atencioso, apontou os rendimentos monetários, em correspondência com as quantidades de arroz e de algodão que entraram no cálculo de cada colono. A identificação de policultura ajuda a entender a complexidade e a diversidade das trocas. Geralmente, quando o lavrador teve rendimento inferior a 50\$000 réis, não se especificou a quantidade de "efeitos" vendidos. Isso significava que podiam ser "efeitos" para consumo local - farinha de mandioca, azeite de andiroba, aguardente, passando por galinhas, mais as pequenas quantidades do produto "rei". Para o lavrador que superava o teto de 100\$000 réis recebidos pela venda, especificou-se a parte relativa ao arroz e ao algodão. Trata-se de refinamentos da contabilidade que apontam pistas sobre as ligações com a Companhia de Comércio por meio da aquisição de patrimônio (escravos, moinhos). Toma-se, assim, conhecimento da capacidade de endividamento assim como do montante do rendimento de cada colono. É necessário observar a dificuldade para conhecer as cargas impositivas da atividade. Os cultivadores de "pouco arroz" não vendiam à Companhia e entravam em relação de dependência com os "negociantes" - compradores de arroz e donos de máquinas. 
Para descobrir como se constituíram as fortunas e as diferenciações internas entre os colonos, pode-se associar a descrição dos vários tipos de unidades camponesas que se diferenciavam pela reserva de mão-de-obra e a condição da exploração agrícola. O grupo que se sustentava sobre os domésticos (parentes e agregados) dependia da capacidade de produzir relacionada com as idades dos seus membros. Antonio da Cunha, casado, tinha no total 9 pessoas, das quais 4 adultos do sexo masculino, e apurou com a sua lavoura 91 \$240 réis. Mas o grupo doméstico, segundo essa caracterização, não mostrava homogeneidade dos rendimentos. Tratava-se de um grupo familiar numeroso, com rendimento ínfimo. Entre os que tiveram um resultado insignificante na lavoura, estavam proprietários de um ou dois escravos, com desempenho igual aos grupos de não proprietários, com mais de cinco pessoas na família, incluindo dois ou mais adultos.

O governador de Macapá, Lobo de Almada, informava ao governador do Pará, João Pereira Caldas, o empenho demonstrado pela vila no comércio do arroz e observava que esse seria maior se os lavradores tivessem recebido ajuda com antecedência, evitando-se "condições indignas" (APP Códice 172). Os lavradores enfrentaram dificuldades diversas, começando por problemas com as sementes, para realizar o replantio. O atraso na colheita provocou demora na seleção das novas sementes, atribuída à falta de bravos para auxiliar os lavradores na tarefa. Vários agricultores participaram da semeadura, limpeza e colheita com o auxílio de "rapazes" e das "índias dos arrozes", cedidos por quatro meses e distribuídos de acordo com critérios e preferências do administrador. Freqüentemente, os colonos ficavam atribulados com os casos de mortes ou fugas dos índios e escravos ou nas alterações da estação chuvosa, que interferiam no calendário agrícola.

\section{OS COLONOS E A COMPANHIA GERAL DE COMÉRCIO DO GRÃO PARÁ E MARANHÃO}

O Pará apresentou descontinuidades no cultivo da gramínea e produziu em ritmo intensivo por curto período de tempo. Várias tensões estiveram presentes de maneira permanente nessa economia agrícola, decorrentes da improvisação política somada às circunstâncias demográficas e econômicas. A rizicultura como busca de possibilidades de aproveitamento das terras inundadas do delta e da planície fluvial amazônica ocupou áreas que pouco se distinguiram por sua densidade demográfica. Em todo caso, isso mostra profundamente uma realidade 
técnica $^{14}$. A costa setentrional, onde mais se desenvolveu a rizicultura, esteve comprometida com fatos de ordem política. Os cultivadores entraram na ciranda da agricultura com condições restritas para transformar-se em plantadores médios.

A análise da agricultura dos colonos converge para um ponto: seu atrelamento a uma política de crédito, dirigida pela Companhia Geral de Comércio ${ }^{15}$, para a compra de escravos, para a aquisição da produção, para o beneficiamento e o transporte e, paralelamente, para a intermediação de "negociantes-colonos". O papel da Companhia depois de 1778 foi desempenhado por agentes individuais que ocuparam o primeiro plano nas transações de beneficiamento, compra e venda da produção. O projeto aplicou uma política severa de tributação da agricultura.

A Companhia de Comércio exportava os "efeitos" (arroz, cacau, anil, salsaparrilha, etc.) comprados dos colonos ou recebia esses produtos em consignação. As diversas transações em regime de monopólio pesaram sobre a vida econômica desses clientes. A venda de produtos importados, denominada "fazenda", era realizada a crédito (escravos, instrumentos de trabalhos, alimentos, tecidos e remédios). A Companhia conseguiu, nessas transações, manter forte controle sobre o crédito, o beneficiamento e o transporte. Ela também exercia a arbitragem dos preços e incluía ainda nos seus papéis o recebimento dos impostos. Constituía dessa forma uma base sólida de poder e de manipulação.

0 contrato era estabelecido na venda e na permuta. A empresa não comprava a "miúdo" e, por cláusula, estava obrigada a transportar as cargas nos seus navios. Na metrópole, a Companhia deveria vender os produtos por preços "nunca menores" e recebia uma comissão pelo serviço.

Os lavradores, no seu nome, faziam carregar as produções nos navios da empresa e endossavam o conhecimento da carga em um dado

\footnotetext{
${ }^{14}$ No rio Purus, na década de 80 do século XX, o industrial norte-americano Daniel Ludwig montou um ambicioso projeto de cultivo de arroz irrigado às margens do rio Jari. O projeto utilizava um sistema de irrigação com base nas marés, próprio da várzea. Foi montado um mecanismo para realizar a drenagem dos terrenos. A produção chegou a $8000 \mathrm{~kg} / \mathrm{ha}$. Aproveitava-se assim o mesmo princípio do regime de marés da rizicultura do século XVIII.

${ }^{15}$ Nas instruções contidas em correspondência para o Maranhão, considerava-se que, dada a abundância, a agricultura do arroz seria um "dos melhores ramos de comércio dessa terra"; portanto, dever-se-ia persuadir as pessoas a cultivarem. A Companhia devia comprometerse a comprar as produções, passando a medida de compra (alqueire) em São Luís para a arroba. Devia ainda fixar o preço pelo arroz descascado e utilizar para as remessas barris, que também eram usados para remeter a farinha de trigo e os biscoitos, ou sacas (AHMFCGGGPM. Carta para o Maranhão XV/R/52, n. 104, fls 134. Carta de 2 de maio de 1767 e Carta de 21 de maio de 1768, fls 141. Documento citado por CARREIRA, 1988, p. 222-223).
} 
correspondente em Lisboa. Algumas vezes não havia sido estabelecido acordo entre a Companhia e os donos dos "efeitos". Os agricultores podiam reconhecer-se livres para transportar os gêneros por sua conta e risco ou confiá-los aos seus correspondentes ou à própria Companhia de Comércio em Lisboa. Na visão de Carreira (1988), criou-se um problema porque "os senhores" interpretaram que eram livres para vender e porque muitos não eram lavradores. Tratava-se das práticas de "negociantes" que revendiam o arroz adquirido diretamente dos produtores ou daqueles a quem os lavradores confiavam a sua produção. A importância dos negócios desse tipo cresceu de tal maneira que houve conflitos dos "negociantes" locais com a Companhia, pois se quebrava a regra monopólica do seu funcionamento.

A vantagem da consignação para os vendedores diretos consistia em obter, na venda dos seus produtos, cotações mais elevadas do que aquelas estabelecidas com a intermediação da Companhia. Os vendedores encontraram nessa relação direta a possibilidade de fugir ou desviar-se do controle da Companhia, sobretudo da situação de devedores de dinheiro à empresa por fornecimentos de crédito, com prazo de pagamento ajustado; em tais casos isso lhes permitia evitar a liquidação das contas. Outra vantagem residia no fato de que as vendas realizadas por intermédio de um correspondente permitiam aos vendedores dispor de dinheiro valorizado, pois utilizam a moeda de mil réis circulante em Portugal, mais favorável que a moeda em circulação no Brasil, cotada por um valor $10 \%$ inferior ao da moeda circulante em Portugal (CARREIRA, 1988, p. 207).

Por esses procedimentos vantajosos, avolumaram-se as remessas de gêneros a supostos correspondentes, e a Companhia declarava estar sendo lesada, contrariada nos seus interesses, de acordo com o artigo 27 do seu Diretório Econômico. Por um lado, o fato de a Companhia não fazer negócios a "miúdo" ou a retalho interferiu no encaminhamento dos negócios com pequenos lavradores; por outro, cresceu uma rede de verdadeiros e de falsos consignatórios. Os "negociantes" (particulares, como denominava a Companhia) abusaram, carregando lavradores e fabricantes de gêneros próprios, e, por meio das compras, atravessavam e fraudavam a Companhia.

Aumentou com isso a fiscalização, e o lavrador necessitou justificar as remessas como "próprias de suas lavras fábricas". Com esse juramento, a Companhia aceitava remeter o produto a Lisboa.

Os "negociantes" organizaram um setor de comércio paralelo ao da Companhia. Impotentes para anular ou impedir sua expansão, as autoridades da empresa declaravam: 
se os lavradores continuarem na mesma prática de buscarem nomes supostos de pessoas que não devem, para debaixo delas fazerem as suas remessas, utilizarem-se das suas importâncias em prejuízo da Companhia; que jamais por este modo será paga do que se lhe deve, enquanto durar este ruinoso tráfico desses moradores, pois é constante que o mesmo produto dessas avultadas remessas, que vêm por conta de partes para esse Estado, torna em moeda corrente a ser novamente empregado e remetido outra vez aos correspondentes que nesta Corte tem públicos contrabandistas, além de vários embarcados por eles, como se encontrou pela tomadia que, nos últimos navios que daqui partiram, se lhes achou a bordo [...] a cuja desordem só V. Ex.a [...] poderá dar o oportuno remédio que nós cá de longe não podemos aplicar (CARREIRA, 1988, p. 172).

Outra rede, que defendia os interesses da Companhia, funcionava entre o produtor direto e os proprietários de engenhos de socar arroz, financiados por ela. Coube ainda à Companhia arbitrar sobre os preços que normalmente eram fixados em níveis mínimos para o arroz descascado. O dono de máquinas de beneficiamento podia transportar no seu nome as quantidades que conseguia juntar por compra do arroz com casca. Esses procedimentos foram idênticos no Grão Pará e no Maranhão. Carreira (1988) admite que a Companhia fazia queixa das fraudes praticadas pelos lavradores, no Maranhão e no Pará, e opinava que no fundo a reação destes não representava mais do que um meio de defesa contra a tirania da empresa. No período de 1770 a 1778, no Maranhão, do total das exportações de arroz - 498.113 arrobas -, somente 56.951 foram em regime de consignação. No Grão Pará, das 63.737 arrobas de arroz transportadas para Lisboa, apenas 16.293 arrobas foram entregues segundo essa fórmula.

O embarque do arroz de Macapá para Belém envolvia a administração local e esferas do Estado colonial. Em novembro de 1775, Manoel da Gama Lobo de Almada anunciava a necessidade de transporte para 16.000 alqueires de arroz. Obter canoas para o transporte do arroz não era tarefa fácil: havia vários trâmites a seguir por vários agentes, que nem sempre respondiam com presteza ou em conformidade com os pedidos. Tanto o transporte como a compra do arroz estabeleceram-se na forma de monopódio da Companhia, que nomeava um comprador local ou um administrador dos "Arrozes" e outro das "Canoas". O primeiro arbitrava o preço de compra do produto e a forma de pagamento do produto, normalmente sem levar em consideração o preço real. Em 1775, em Macapá, esse funcionário pagou 320 réis pelo alqueire, abaixo do preço real, pois sabe-se, por outras fontes, que a arroba de arroz descascado estava cotada a um preço que variava de 500 a 775 réis (CAR- 
REIRA, 1988, p. 138-139). O gênero, quando não havia ficado na terra pela falta de braços para a colheita, corria o risco de ficar no paiol. Desse fato, resulta uma relação pequena de colonos de Macapá que colocaram arroz diretamente no mercado de Belém e Lisboa. Da lista nominal dos residentes que haviam consignado arroz nos navios da Companhia de Comércio, constavam o capitão Estevão da Silva Jacques (1764), João Francisco (1774-1776 a 1778) e Manoel de Miranda (1762-1764) ${ }^{16}$. No campo das relações creditícias, existem poucos documentos. Muito menos material para examinar as articulações horizontais entre os "negociantes" e os colonos. Isso dificulta o acesso à contabilidade doméstica dos diversos segmentos. A questão central está em montar o quadro de despesas do agricultor, mas trata-se de um grupo com um perfil diferenciado - os de maior articulação com o mercado para vender em consignação ou comprar mercadorias; e aqueles que estabeleceram níveis de consumo e de comercialização por intermédio dos donos de máquinas e compradores de arroz.

Na cadeia da comercialização, ocorriam transações de negociantes compradores com os produtores diretos, e seria interessante conhecer, para os diversos produtos intercambiados, a regularidade, a forma da transação, os agentes. A comercialização do arroz constitui um corte no processo mais amplo de trocas numa economia agrícola. Os produtores que vendiam para a Companhia de Comércio aparecem como compradores-consumidores das mercadorias importadas. Em 1775, os moradores de Mazagão solicitavam o pagamento em "fazendas" secas em troca da produção de arroz. Foram atendidos, recebendo o equivalente a 400 réis - valor do alqueire - em mercadorias diversas: sal, pólvora, tecidos. Esse esquema freava a circulação da moeda e fez-se acompanhar do avanço progressivo do endividamento nos armazéns da Companhia, o que se transformou em um "mal" crônico. O agricultor de "possibilidade escassa" entrava marginalmente no sistema, pois era norma da Companhia realizar as transações em grandes quantidades, já que havia vedado as vendas a miúdo ${ }^{17}$.

\footnotetext{
${ }^{16} \mathrm{O}$ sal encontrava-se entre as mercadorias mais procuradas e de lucratividade mais elevada. Pelo decreto de 7 de julho de 1757, proibiu-se expressamente a venda de sal por preços elevados aos moradores do Maranhão e Pará. A Companhia vendia a 540 réis o alqueire; no Pará ficava por 1749 réis. O sal era usado para o gado e para o salgamento do peixe (CARREIRA, 1988, p. 167).

${ }^{17}$ Esse dado resulta da comparação dos agricultores citados nos CODICES de Macapá e no documento n. 60 da obra de A. Carreira (1988).
} 
A Companhia agia na suposição de poder vender por dinheiro as "fazendas" e os escravos. Realizava venda a crédito somente entre "pessoas notoriamente abonadas" para evitar riscos de perdas. Os colonos compravam bens de consumo (facões, tecidos, sal, remédios) de revendedores. No recenseamento, anotaram-se as declarações de rendimento em moeda da maioria dos lavradores que apuraram pequenas quantidades de arroz e algodão. O teto inferior foi de $9 \$ 000$ réis, por sua lavoura, pagamento recebido provavelmente por venda ao "grande" comprador de arroz e revendedor de mercadorias importadas.

O lavrador que comercializava diretamente em Portugal, após diversos cálculos de despesas - transporte, despachos, impostos -, recebia o saldo líquido de venda, transmitido aos representantes no Brasil com instruções no sentido de pagar de "preferência em fazenda ou gênero". Se o consignador era devedor, o saldo servia para amortizar ou cancelar a conta (CARREIRA, 1988, p. 172).

Era difícil agir com independência, escapar ao controle exercido pela Companhia de Comércio. Antonio Vaz, rico proprietário de olaria, dono de curral, máquina de descascar arroz, escravos e solicitante de terras na ilha Caviana para seus filhos, esteve envolvido num pleito administrativo esclarecedor. Luís Bernardo Lopes de Oliveira e José Baptista, administradores da Companhia, relataram a transferência de uma carga de propriedade de Antonio Vaz (de 1032 alqueires de arroz) a ser recebida por Antonio Pocego em Lisboa. Os administradores negaramse sistematicamente a realizar essa transação junto ao agente estatal. O governador João Pereira Caldas ordenou ao negociante que vendesse o arroz aos armazéns reais sob ameaça (APP Códice 178). O objetivo era diminuir o poder de Vaz, sério concorrente da Companhia. Ambos os agentes articularam-se para sujeitar a maioria dos lavradores. Ao final, nesta parte do mundo colonial, eles manipularam os elos mais sólidos e permanentes para se apropriar do excedente. A estrutura de poder e a rede intrincada de dependência marcaram integralmente a agricultura e foram decisivas na vida dos colonos.

Os especialistas em história agrária propõem, para o estudo do rendimento agrícola, considerar a quantidade de sementes plantadas por unidade de superfície ou a relação de grãos semeados/grãos colhidos ou o rendimento em tonelada por unidade de superfície cultivada (CARDOSO, 1979, p. 13-94). Para Macapá e Mazagão, esses dados são escassos e incompletos, é difícil, portanto, avançar mais na base factual. Existem especulações sobre a quantidade de sementes destinadas ao replantio de arroz. Almada calculou, no seu Plano, que 20\% da produção deveriam ficar para sementeira e alimento da vila. Em 
geral, a lacuna é considerável nas superfícies cultivadas, nas técnicas de cultivo, nos rendimentos e custos.

Calcular os acréscimos de mão-de-obra e as despesas nas diversas fases da produção também não oferece confiabilidade. Em Macapá, o incremento da população para as necessidades da produção foi temporário mas, sobretudo, difícil de estimar, pois cita-se muito irregularmente o número de mulheres indígenas trazidas para realizar a colheita. Dois raciocínios ajudam a entender a questão de despesas. O primeiro diz respeito às despesas prévias com a compra de escravos e com a manutenção destes e os agregados. O engajamento do agricultor na compra do escravo é indissociável do início na atividade agrícola e das ocorrências dos preços e de produtos da lavoura.

A propósito dos escravos adquiridos no Maranhão e no Pará por intermédio da Companhia de Comércio, existiam diferenças entre os moradores das duas capitanias. O administrador da Companhia de Comércio no Maranhão determinou que a chamada flor (classificação para os melhores escravos) se vendesse somente até 100.000 réis por cabeça e assim gradualmente, cada vez marcando preços menores. Mas os agricultores foram afetados por situações de escassez ou de vendas realizadas a preços dobrados. Recorriam à "fiança" por "preços de 230 a 500 mil réis", e deviam satisfazer os altos juros dos vencimentos. O preço do escravo de 85.000 réis podia ser elevado para 100.000, até finalmente ser vendido por 160.000 réis (o equivalente a 150 alqueires de arroz e a 50 alqueires de algodão). Isso nas operações com uso de dinheiro, fato excepcional nas trocas do período. No caso do fiado, o juro da lei na praça maranhense era de $6 \%$ desde o dia da venda "até ao embolso", enquanto o prazo de cancelamento dos créditos era de um a três anos (GAIOSO, 1970, p. 247).

O segundo raciocínio envolve os encargos e pagamentos. Carreira (1988, p. 206) expõe que, no Pará, de modo geral, recaíram sobre os gêneros encargos superiores aos do Maranhão. Examinou as fichas da Companhia de Comércio e sistematizou todas as despesas. Conforme o autor, as despesas incluiriam os seguintes itens: a) pagamento do dízimo da produção e do produto exportado; b) despesa com o descaroçamento ou descasque; c) aquisição da sacaria e preço pago pelo ensacamento; d) fretes de transporte (desde os centros até as cidades) das mercadorias de exportação. Daí depreendem-se os mecanismos de expropriação do excedente do lavrador por meio da cadeia da comercialização. Carreira elabora uma relação das despesas na origem e na Casa da Índia, em Lisboa. Listou como despesas na origem: sacaria e ensacamento (60 a 80 réis por arroba), capatazia (5 réis a arroba), comissão da Companhia 
(4 a 8\%), direitos alfandegários (5 a 7\%), dízimo, novo direito - criado em 1771 - (2\%), Ver-o-Peso (30 réis por saca) e subsídio (100 réis por arroba).

Os lavradores ou os compradores de arroz deviam pagar a "maquia" em espécie ou em dinheiro. Era a percentagem desembolsada para pagamento do descasque do arroz nos moinhos da Companhia. O dízimo pago à Fazenda Real era de $10 \%$ do produto beneficiado nas "fábricas" (descaroçamento e descasque). Geralmente era pago em espécie. Nesse ato também se buscava diminuir as dívidas contraídas com a compra de escravos e o pagamento dos juros.

Em Lisboa, na Casa da Índia, pagavam-se: direitos alfandegários (13 a 18\%), Consulado (3\%), donativo (4 a 5\%), obra-pia (1\%), colégio (100 réis por peso líquido), amostra para a avaliação (80 réis por cada 6.000 réis), descarga (14 a 40 réis por saca), carreto, tara e transporte (140 réis por peso líquido), Juiz da Mesa do Peso (20 réis por peso líquido), Guarda de Companhia, contribuição (20 réis por saca), porteiro, comissão para a Companhia (2 a 4\%). O sistema de fiscalização depurativa era extremamente pesado. Para o outro lado da cadeia, o negociante comprava "pelo que lhe faz conta" (CARREIRA, 1988, p. 291), e os lavradores dependiam dos comerciantes e dos beneficiadores. Entre os agricultores sujeitos à comercialização forçada, estava o grupo de pequenos produtores. Gaioso (1970) ${ }^{18}$ comparou as despesas no cultivo do algodão e as do arroz e supôs existir complementaridade entre ambas. Para seu exercício de cálculo, baseia-se em dados de 1783 e constata que geralmente o trabalhador vendia ao negociante, pois não tinha condições de transportar.

Finalmente, os agricultores pleiteavam o pagamento em dinheiro do arroz dos administradores da Companhia de Comércio. Cinco anos depois de os lavradores do arroz terem começado o plantio no Maranhão, por intermédio do governador, solicitaram aos deputados da Companhia facilidades para o custeamento de "fazendas" (mercadorias vindas da Europa) e pediam pagamento do arroz em "dinheiro". Esse apelo dos agricultores fundava-se em um raciocínio simples: o preço do arroz era mais baixo, mas o cereal estava sendo produzido em maiores quantidades e representava menor despesa para o agricultor; com a venda em dinheiro, os agricultores podiam equilibrar a situação financeira e, inclusive, pagar as despesas com o algodão,

\footnotetext{
${ }^{18}$ Admitindo lacunas e reservas em relação aos dados de Gaioso, toma-se como referência sua demonstração das despesas. No final, o autor pensava um sistema diferenciado de arrecadação do dízimo no Maranhão.
} 
bem mais elevadas. Assim, o recebimento pelo algodão seria aplicado para pagamento dos suprimentos e desembolsos comprometidos com a mesma Companhia. Completaram o pedido solicitando a redução do preço dos escravos, ajustado às suas condições financeiras. Esse segundo "rogo" dos lavradores foi atendido com a primeira escolha de escravos introduzidos e com a fixação do preço máximo ou teto.

$\mathrm{Na}$ análise das estruturas camponesas da Amazônia colonial, a questão das formas de funcionamento e dos rendimentos das unidades de produção tem interesse especial, embora seja um dos pontos menos sólidos da documentação histórica. As peças para produzir esse conhecimento ainda não foram suficientemente esclarecidas. Existe uma lacuna quando se comparam informações sobre os engenhos e as Companhias de Comércio. Estudiosos como Carreira (1988) e Dias Nunes(1970) apresentam a contabilidade da Companhia de Comércio, entretanto, sente-se falta de inclusão das contas dos lavradores. O tipo de contabilidade macro permite o conhecimento dos negócios em escala ampliada, articulações no sentido vertical da Companhia e as redes agindo no Pará, mas certamente é lacunoso o sistema de crédito ao produtor.

\section{CONCLUSÃO}

Os problemas dos agricultores de Macapá não podem ser atribuídos apenas às irregularidades da produção de arroz provocadas por situações especialmente negativas da natureza (solos, insalubridade dos sítios, regime de marés). Ao que tudo indica, não se registraram situações calamitosas, capazes de desestimular o plantio ou provocar uma queda na cultura.

É necessário encontrar outras explicações. A primeira concerne ao mercado e aos preços. Nos três primeiros anos, o preço do arroz foi desestimulante. Em 1773, os lavradores receberam 400 ou mesmo 350 réis. Dada essa situação, ao exigirem uma resposta dos administradores da Companhia sobre a queda do preço, receberam como explicação a existência de grandes quantidades de arroz estocadas em Lisboa. Carreira, compilador de documentação original sobre a empresa, elaborou uma visão parcial, dizendo que haviam reagido mal os lavradores às freqüentes alterações na política de preços e de facilidades que a empresa estava seguindo. Na verdade, a explicação é outra. Já foi indicado o peso das despesas proibitivas e a elevada taxação que transformavam 
a produção em não compensadora. Os lavradores encontravam-se em uma situação de comercialização forçada, precisavam vender para pagar dívidas e obrigações e respondiam à diminuição do preço do arroz, produzindo e vendendo mais.

Os agricultores de Macapá dispuseram de terras livres, com capacidade de produção relativamente homogênea. Mas haviam perdido a liberdade de comercializar sob a forte pressão dos transportadores e comerciantes, que ainda controlavam as máquinas de beneficiamento do arroz. Tudo indica que foram as dívidas, a fiscalização e especialmente os baixos preços pagos pelos produtos que forçaram a maioria dos agricultores a submeter a uma intrincada dependência até os afundar no estado de "miséria", de que reclamava Lobo de Almada. Beneficiamento e transporte mantiveram os produtores em situação de dependência. Em Macapá e Mazagão, encontravam-se pequenos produtores de arroz, na dependência das canoas dos compradores de arroz. A forma de comercialização afetou profundamente os pequenos produtores diretos e gerou níveis de extorsão elevados. O sistema articulou a venda a crédito, por conta da produção, das mercadorias européias. Após a saída da Companhia de Comércio do Grão Pará e Maranhão, desenvolveu-se outro movimento na agricultura dos colonos. Diminuiu a produção de arroz, e as unidades familiares reforçaram atividades de policultura e extrativismo. Macapá produziu mais farinha e algodão do que arroz. A lista dos seus produtos ainda incluiu feijão, milho, café, tabaco. Macapá passou a ser mais conhecida no mercado interno pelos panos de algodão provenientes do beneficiamento desse gênero; as relações com o mercado de Belém ficaram mais importantes.

A vila de Mazagão e cercanias mostravam algumas décadas depois o espaço da agricultura, aparentemente mais estável com pequenas plantações de algodão na ilha Pará, "o único gênero de lavoura que exportam"; de resto, era farinha de mandioca para o consumo plantada nos rios Preto e Maracá. Ainda se cultivava "pouco arroz, milho, feijão e algumas frutas; abrangem na sua acanhada agricultura de cana-doce" (APP Códice 1002).

A representação de fracasso e decadência da primeira colônia de Macapá levou, no século XIX, à recolocação em cena de objetivos e interesses militares de ocupação da costa setentrional. Novos episódios de disputa de fronteiras, na primeira década, desembocaram na tomada de Caiena durante nove anos. Em 1840, o governo provincial fundou a segunda colônia, conforme um modelo abertamente militar: 
a colônia Dom Pedro II, localizada à margem direita do rio Araguary, a 16 léguas ao norte de Macapá. Fixou-se o objetivo de desenvolver a agricultura, mas não foi redescoberta a associação com a rizicultura nem com o delta amazônico. Entre o Pará e o Maranhão, a diferenciação maior está na (des)continuidade histórica do arroz, cultivo de profundo significado nas raízes da história agrária e do campesinato de ambas as regiões. 


\section{REFERÊNCIAS}

ALDEN, Dauril. Colonial roots of Modern Brazil. Berkeley: University of California, 1973.

ALMEIDA, Alfredo Wagner Berno de. A ideologia da decadência: leitura antropológica a uma história da agricultura no Maranhão. São Luis: IPES, 1983.

BAENA, Antonio Ladislau Monteiro. Ensaio corographico sobre a província do Pará. Belém: Typographia de Santos G Menor, 1839.

Compêndio das eras da província do Pará. Belém: Universidade Federal do Pará, 1969.

BARATA, Manuel de Mello Cardoso. A antiga produção e exportação do Pará. Belém: Typ. de Livraria Gillet, de Torres e Comp., 1915.

BOXER, C. R. A idade de ouro do Brasil: dores de crescimento de uma sociedade colonial. São Paulo: Companhia Editora Nacional, 1969 (Brasiliana, 341).

BRASIL. Arquivo Nacional. Documentos históricos. Rio de Janeiro, 1928, V. 2 .

BRAUN, João Vasco Manuel. Relato da Viagem do Naturalista João Vasco Manuel Braun em 1784. Jornal do Instituto Histórico e Geográfico Brasileiro, [S.l.], n. 15, 3 Trim. 1849.

CARDOSO, Ciro Flamarion S: Agricultura, escravidão e capitalismo. Petrópolis: Vozes, 1979.

CARREIRA, Antonio. A Companhia Geral do Grão Pará e Maranhão. São Paulo: Editora Nacional, 1988.

DANIEL, João. Tesouro descoberto no rio Amazonas (1757-1776). tomo

2. Rio de Janeiro: Biblioteca Nacional do Rio de Janeiro, 1976. 457p.

DIAS, Manuel Nunes. A Companhia Geral do Grão Pará e Maranhão (1775-1778). Belém: UFPA, 1970 (Coleção Amazônica, Série José Veríssimo). 
FERREIRA, Alexandre Rodrigues. Viagem filosófica ao rio Negro. Belém: Museu Paraense Emilio Goeldi/CNPQ, 1983. 775 p.

Propriedade e posse das terras do Cabo do Norte pela Coroa de Portugal. Revista do Instituto Histórico e Geografia, Rio de Janeiro, t. 4, 1841 .

FUNDAÇAO INSTITUTO BRASILEIRO DE GEOGRAFIA E ESTATÍSTICA. Geografia do Brasil: Região Norte. Rio de Janeiro, 1989.

Atlas do Amapá. Rio de Janeiro, 1956.

GAIOSO, Raimundo José de Souza. Compêndio histórico-político dos princípios da lavoura do Maranhão. Rio de Janeiro: Livros do Mundo Inteiro, 1970.

GOURIOU, Pierre. Riz et civilisations. Paris: Fayard, 1984.

HAUDRICOURT, André-Georges. La technologie, science humaine: recherche d'histoire et d'ethnologie des techniques. Paris: MSH, 1987.

LE COINTE, Paul. L'Amazonie brésilienne. Paris: Augustin Challamel Editeur, 1922 (2t.).

MACEDO, Jorge Borges de. A situação econômica no tempo de Pombal. Alguns aspectos. Porto: [s. n.], 1951.

MAM-LAM-FOUCK, Serge. La Guyane Française du XVII ${ }^{e}$ siècle à 1960. Paris: Desormeaux, 1982.

MENDONÇA, Marcos Carneiro de. A Amazônia na Era Pombalina. tomo 1. São Paulo: IHGB, 1963.

NEVES, WaIter A. (Org.). Origens, adaptações e diversidade biológica do homem nativo da Amazônia. Belém: MPEG/CNPq/PR, 1991 (Coleção Emilie Snethlage).

REVISTA DE HISTÓRIA. Os portugueses no século XVI e a história natural do Brasil. Publicação trimestral, Lisboa, v. 15, p. 35-166, 1928. 
SPIX, Johan Baptist Von; MARTIUS, C. F. O. von. Viagem pelo Brasil: 1817-1820. São Paulo: Melhoramentos, 1976.

VERGOLINO-HENRY, Anaiza; FIGUEIREDO, Artur Napoleão. A presença africana na Amazônia colonial: uma notícia histórica. Belém: Arquivo Público do Estado do Pará, 1990.

\section{Fontes primárias}

Mappa de Todas Famílias que existem na Freguesia de Sam Joze de Macappa, da força das suas lavouras e serviós, e da quantidade e qualidade de effeitos e colheitas que ellas produzirão em todo o anno de 1778.

Mappa das Famílias, que, a excepção das dos índios aldeados se achavão existindo em cada huma da mayor parte das freguesias de ambas as capitanias do Estado do Para e de sua possibilidade e applicação no anno de 1778.

Arquivo Público do Estado do Pará

Códices da série "Diversos com Governo"

Códice 1331773 II Semestre

Códice 1451774 I Semestre

Códice 1551775 II Semestre

Códice 1561775 I Semestre

Códice 1741777 I Semestre

Códice 1721777 II Semestre

Códice 150 (1777-1781)

Códice 178 (1777-1781)

Códice 2011780

Códice 2101781

Códice 1002-1823 


\section{Anexo}

\section{APP Códice 174}

Anexo ao Documento 46 (Transcrição) Data: 04.abril.1777

Plano pelo qual se offerece a que do porto de Macapa saião todos os annos ao menos cem mil arroubas de arros.

4 de abril de 1777.

As sircunstancias geraes que se requer para huma similhante lavoura são haverem terras; braços que as cultivem; lavradores que adiministrem o trabalho com zello, que tenhão esperiencia e genio; são necessarias ferramentas, e hé precizo que hajão mantimentos. A extração, o valor e as mais sircunstancias q'sedeichão de tocar hé por que se achão já adevertidas por Sua Exellencia o IImo e Exmo Snr. General.

Enquanto a primeira se acha examinado por lavradores de toda até como são André Correa Picanço, e outros que mandados aver se havião terras proprias, enformarão que as acharão proprissimas com muitas ventagens embeneficio da referida cultura.

Enquanto a segunda parte. Hum homem lavra sincoenta alqueires de arros, sao logo necessarios para cem mil alqueires dois mil homens.

Macapá tem efectivamente entre os lavradores =

$\begin{array}{ll}\text { Homens de trabalho } & \$ 110 \\ \text { Negros de Machado } & \$ 172 \\ \text { Índios de Portaria } & \$ 111 \\ \text { Que fazem ao todo } & \$ 293\end{array}$

Para lavrar 100\$000 alqueires são necessarios como já disse 2\$000

Para se segurar o referido pé de $2 \$ 000$ homens de trabalho efectivamente necessarios descontados os doentes e mortos que racionavelmente pode suporse e ainda alguns negros que poderão fugir hé precizo haverem mais $\$ 300$.

Fazem o Estado que efectivamente se requer $2 \$ 300$.

Mas não há senão o numero que faz ao todo \$293.

Hé precizo pois que Macapá seja socorrido com mais 2\$007.

Bem se sabe que os índios e índias de todos os lugares e Villas do Estado empregados na cultura de arros nunca chegarão a fazer colheita a que se oferece Macapá.

Sabece que emquanto o Estado confiar alguma couza de Directores não pode levar muito longe as suas esperanças: As couzas que os tem feito conhecer não são propriamente deste asumpto, e são muito claras para que não a vejão todos. 
Parece logo muito a prepozito que os Índios sejão destribuhidos porquem os saiba conduzir ao interece publico não só do Estado mas ainda do Reino.

Este socorro de Índios que se requer, se faz ainda menos violento, por que só se pede emquanto a Companhia Geral não pode dar a Macapá os escravos de que secarese: E também porque se for possível darem se ja, mais alguns Negros bastara então menos numero de índios.

Ora, adarse o pedido socorro de gente hade ser o tempo de que o primeiro de Agosto precizamente se entre a roçar; porque se a lavoura do arros se principia aqui com a Estação mais avançada, se encontrão suas incomodidades, que as vezes cauzarão perda grande.

Passando a $3^{\circ}$ parte sevê que Macapá tem 162 lavradores, isto hé pessoas capazes de se lhe confiar a lavoura por experiencia, e conhecimentos que há, cujas pessoas se nomearão logo para que se possa conhecer dellas.

Para confiar de 162 lavradores a lavra de 100\$000 alqueires basta que sefaça lavrar a cada hum 617: E não se pode duvidar de taes lavradores que cada hum lavre a limitada porção de 617 alqueires quando se acaba dever que elles não obstante o perderem muito arros na terra por falta de gente que o apanhase a tempo lavrarão com tudo na última colheita que handão entregando de 24\$000 alqueires para sima. Logo bem se ve que há lavradores deque sefaça toda a confiança; maiormente se hé certo que a força vinda augmenta.

Em $4^{\circ}$ lugar hé necessário que a Companhia largue aqui para sima de 1500 machados, e outras tantas fouces porque a falta de ferramentas tem sido hum obstaculo que tem costado a suprir.

Finalmente e no $5^{\circ}$ e ultimo lugar hé precizo que quem trabalha coma. Ora a lavra que promete $100 \$ 000$ alqueires promete $120 \$ 000$ arroubas, mas elle não se oferece mais do que 100\$000 arrombas. Logo bem seve que deichão $20 \$ 000$ arroubas ou 16\$667\% alqueires com pouca deferença para continuar a sementeira e sustentação da Villa. Macapá costuma dar farinha para se sustentar; atendida esta razão, e considerados os 16\$667\% alqueires de arros, referidos, seria logo precizo que só entrassem mais 9\$132 alqueires de farinha para sustentação de $2 \$ 007$ bocas que entrão demais: Porem a respeito de farinha qual quer porção que possa vir, e alguãs providencias que se achão dadas com antecipaçaõ a suprir esta falta isso bastara em quanto a esta parte.

Precizase de carne ou pexe seco $10 \$ 000$ arroubas.

A continuar a Companhia as remessas do Sal que tem principiado fica desnecessario tocar este ponto.

Tem parecido que este Plano hé de facil execução ao menos em parte; isto hé que quando senão poça dar o numero de gente pedido; sempre para 
argumentar este ramo de comercio se deicha bem ver, que se os índios que os Diretores ocupão nas roças do arros se dessem a Macapá, facilmente severia que Chaves podia dar mais de 700 alqueires, Outeiro mais de 200, Fragozo mais de 390, Porto de Mos mais de 17 o que nenhua das dittas Directorias fez; assim como as mais que sempre o derão e darão não só em muito menos quantidade do que lhes premitem as suas forças; mas ainda muita parte insuficiente por não saberem o tempo de colhelo, nem o modo de beneficialo; cujas sircunstancias, e outras muitas que tendem a perfeição e adiantamento do mesmo objeto; não podem alcançarse, sem que o zelo da utelidade publica e do Serviço do Princepe; seja a principal roda que faça mover a maquina das nossas ideas em favor dos nossos enteresses.

Ultimamente se este Plano for observado em todo o seu espirito, se reconhecera não haverem outras razoens que o inspirasem, senão em primeiro lugar o promover huma Agricultura tão recomendada das Ordens de S. Mage. que tanto cuida em fazer felizes os seus povos.

Em segunda razão o haverse reconhecido para esta lavoura o empenho de hum General que meresse que os seus subaltemos se esforcem a ajudalo. E finalmente em ultimo lugar o concorrerse para que hum povo digno de toda a porteção situado em huma das milhores partes do Estado, passe de huma situação de mizeria e de operção, a poder respirar, e a ser util a sua patria, e ao seu Soberano. 